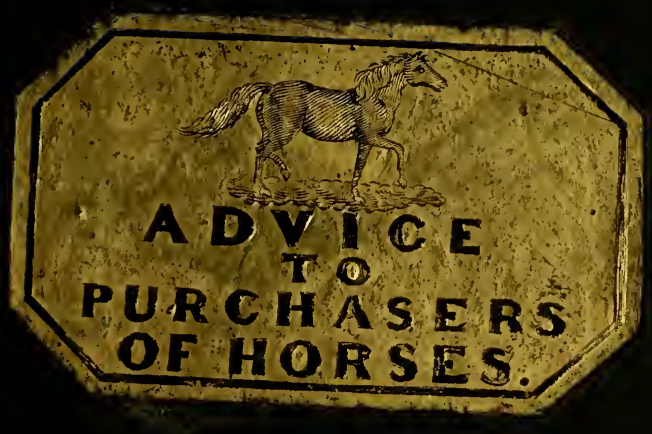


万 


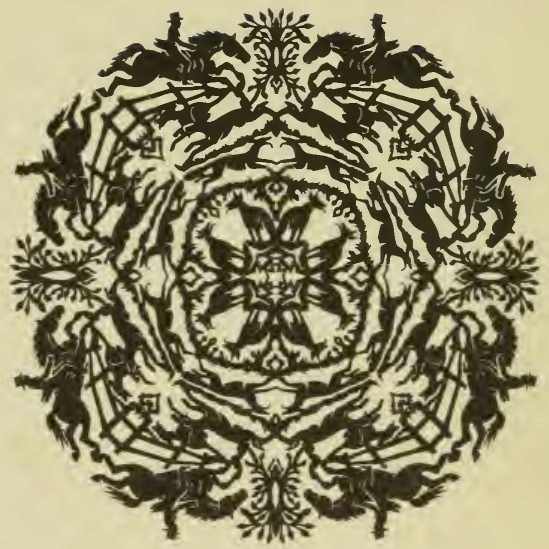

JOHN A.SEAVERNS 


$$
\text { - }
$$





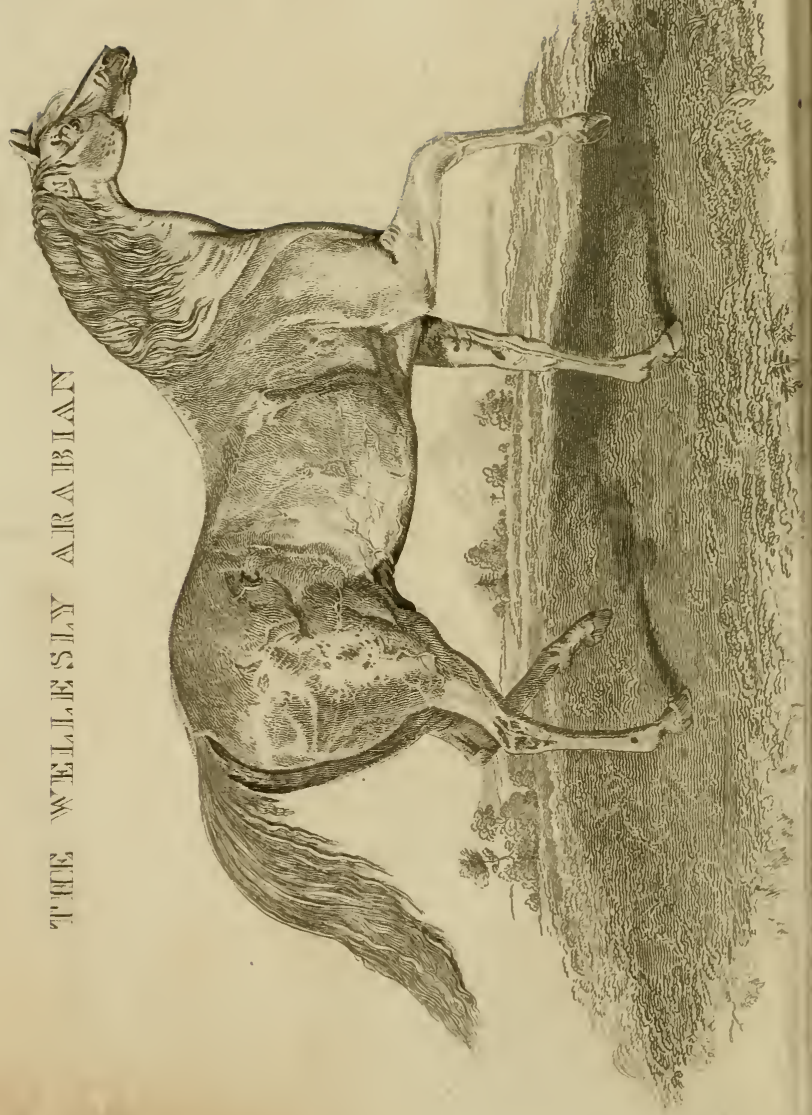




\title{
ADVICE
}

To

\section{PURCHASERS OF HORSES;}

BZING A SHORT AND FAMILIAR TREATISE ON THE EXTERIOR CONFOR VATION OF THE hORSE; THE NATURE OF SOUNDNESS AND UNSOUNDNESS; AND THE LAWS RELATING TO SALE AND WARRANTY; WITH COPIOUS DIRLCTIONS FOR DISCOVERING UNSOUNDNESSES PRIOR TO PURCHASING.

\section{Bx J. S T E W A R T,}

VETERINARY SURGEON, AND PROFESSOR OF VETERINARY SURGERY IN THE ANDERSONIAN UNIYERSITY.

"The buyer hath need of an hundred eyes, But the seller of anly one."

\section{THIRD EDITION.}

\author{
PRINTED AT THE \\ Glasgow University Press. \\ PUBLISHED BY W. R. M'PHUN, 86, TRONGATE, \\ SIMPKIN AND MARSHALL, LONDON.





\section{CONTENTS.}

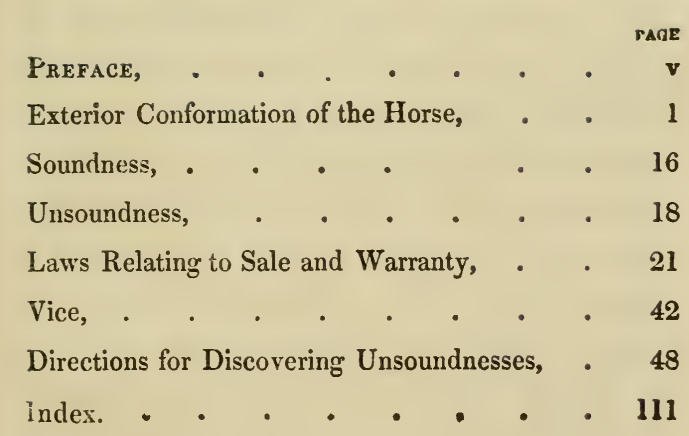





\section{PREFACE.}

There is no species of traffic in which the purchaser runs greater risk, exposes himself to more imposition, and experiences more disappointment, than in that of horse-dealing. There is none in which so little confidence is placed in the seller; and, generally speaking, there is none in which greater ignorance is displayed by both, in judging of the soundness of the commodity. The buyer inquires " is the horse sound?" the seller replies "warranted sound," and makes himself responsible for it by giving a written certificate. As the word sound forms such an important part of the contract, we might expect that its meaning would be well defined, and clearly understood in the same sense by both parties. But no such thing; on the contrary, not two 
out of an hundred attach the same meaning to it. One says, a horse is sound when free from lameness; another enumerates a certain number of diseases, such as spavin, broken wind, glanders, \&c., the existence of any of which makes a horse, in his opinion, unfit to be warranted, but no two agree as to the kind, or number of diseases. Hence arise misconception, litigation, suspicion of knavery, and the low estimation in which the dealer is too generally held. Many people are not aware while they vilify the dealer for palming an unsound horse upon them, that it is quite possible he knew nothing about the unsoundness. It is only under certain circumstances that he can know more of the horse than the purchaser (if a horseman) would, after possessing him the same length of time. For the truth is, the majority of men embark in horse-dealing with scarcely a qualification requisite for conducting it, with profit to themselves and satisfaction to their customers. It is not enough to be a toler- 
able judge of a horse's shape, to have tact in buying at a low rate, and selling at a high one. In order to select with judgment, and recommend with confidence, some knowledge of the structure and diseases of their merchandise, should be added to their ordinary qualifications. With such information, the dealer would be much less exposed to the mortification of having his horses returned for what he knew nothing about-his warranty would be more valuable-he would be more trusted to, and stand higher in public estimation.

While the ignorance of the dealer is one great source of dispute, his undoubted dishonesty is another. "Too many," as I once heard an experienced and intelligent horseman remark, "begin business who have neither principle nor capital," and whose whole life is spent in downright imposition. They buy up a lot of lame or worn-out horses, try their skill in removing or healing their worst faults, and then resell them to some small 
farmer, or poor carter; and thus, these a espicable rascals, like quacks, contrive to live by robbing the poor. It is some consolation, however, that they are not nearly so numerous as they were some years ago. Men of respectability and information are gradually pushing them out of the field.

The dealer is not always in the wrong. It is imagined by many purchasers, that the warranty makes the seller responsible for whatever may happen the horse for a certain period after sale; some say three weeks, some three months, and others, still more rapacious, would have it extend to six months. Now, by referring to the article on warranty, it will be seen that though the horse dies a day, an hour, or even a minute after the completing of the sale, yet the purchaser must bear the whole of the loss, unless it can be proved that the canse of death existed at the moment of sale. Few men would be foolish enough to warrant a horse, at any price, if the law were such as it is so commonly supposed. 
Indeed as it is, some gentlemen when selling their horses, have been so much annoyed that they have given up warranting altogether; and they contend that it is upon the whole the best way. But to me it appears otherwise; for it would encourage all sorts of knavery, the purchaser would be completely at the mercy of the seller, and it would very much impede the transaction of business. It is often said that a horse is like a lottery ticket, but he would be much more so if he were never warranted. The irregular mode in which horse-dealing is managed, makes it more a lottery than it naturally is. Alter the system, and fewer warranties will be asked, and fewer objections will be made to granting them. The purchaser cannot return the horse without a veterinary surgeon's certificate that he is unsound, and that the cause of that unsoundness existed prior to sale; and therefore the seller runs no risk, if the horse is really sound when sold. He should, however, reject the opinion of a 
man who is not qualified to give one. But now I am getting out of my province; this book is written for the purchaser.

In the following pages I have endeavoured to supply the horseman with what he must often have felt the want of. I believe there is no separate treatise in the English language on the examination of purchases, and, with the exception of the author of the "Horse" in the "Library of Useful Knowledge," our authors are all too scholastic, and too voluminous to be useful to an ordinary reader.

GlasGow, October, 1833. 



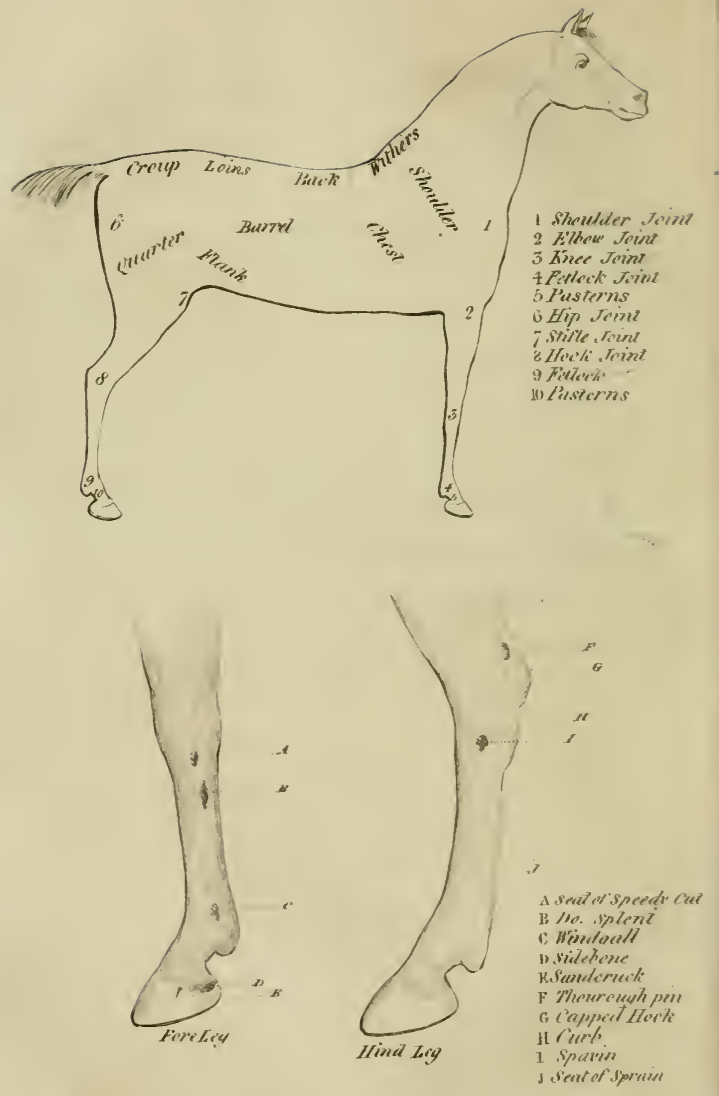




\section{A D V I CE}

To

\section{PURCHASERS OF HORSES.}

\section{Exterior Conformation of the Horse.}

There are some peculiarities in the form of the horse, which admirably fit him for one kind of work, but at the same time render him useless, or nearly so, for another. The racer, with his light airy form, delicate limbs, rapid movements, and fiery spirit, is eminently an animal of speed; but yoked to a heavy waggon along with a stout cart horse, he appears comparatively weak and worthless. Though one horse, from his conformation, is best fitted to carry, and another to draw, and another still to do both with decency, yet there are certain points, which it is desirable to have in all horses, for whatever work they may be designed. Such, for example, is a large nostril, which is a good quality in all, and does not, like some others, become a bad one, when the horse is applied to a different purpose. But then, it is one of far more consequence in a horse 
wanted for quick work. than one whose pace need never exceed a walk. In the one case, it is absolutely requisite, but in the other, is only a secondary consideration.

The horse in most general use, is a compound of the speed of the racer and the power of the draught horse : and it is the different proportions in which these qualities exist, that make one a hunter, another a hackney, \&c. To explain how a certain form makes one horse fleet, and another powerful, would, in most cases, lead to an anatomical consideration of the whole machine, so that in the majority of cases, I can only state the fact, and those who wish for more, may obtain it by some dissection, and a careful perusal of " The Horse," in the Library of Useful Knowledge-a work, by the way, which no admirer or proprietor of the horse should be without. I shall only observe here, that difference in form is almost entirely produced by the relative proportion (length generally) of the bones, and the position they occupy. The muscles are the organs of motion, and in proportion to their development, the animal is strong, but the bones being the levers upon which the muscles act, that strength, and the horse's action, must be considerably in- 
creased or diminished, according as the bone they are attached to is longer or shorter than is usual. The strength is likewise much, and, generally speaking, the extent of action more, influenced, by the position of the bone, as in the case of the shoulder blade, which by being long, and slanting from the withers forwards and downwards, gives the horse extensive action as well as strength, while a more upright position (and if upright, it must be short likewise) of the same bone, confines the action of the whole limb, and reduces the power of the muscles. The bones, besides, sustain and give form to the whole structure, and add considerably to the weight: consequently their bulk in the draught horse is not a serious objection, for he does much of his work by throwing his weight into the collar, and as it were pushing it before him.

Notwithstanding the importance of conformation, it is not all that is required. Experience reminds us, that many seemingly faultless animals have lamentably disappointed the expectations their figure had raised, while others, as insignificant in appearance as may be, have surprised good judges by their extraordinary and unlooked for performances. Hence, many horsemen ex- 
claim, that "there are good horses of all shapes." The fact is, a great deal depends on the quantum of nervous energy or "bottom" which the animal possesses, and it is the union of this energy with good conformation that makes many horses invaluable. Its absence or presence, however, is not likely to be discovered by the purchaser without a trial : and to avoid disappointment in this respect, it is therefore advisable to obtain one prior to purchase. The horse should be set to the work he will be called on to perform, and if he is intended for the saddle or single harness, he should have no companion on his trial, for many horses work well in company, that are downright sluggards when alone.

Some horses have an unpleasant way of going, or are difficult to manage, or have some vice which is only displayed at work. These are so many more reasons for having a trial prior to striking a bargain. But if that cannot be obtained, some sort of conclusion regarding the animal's spirit may be drawn from his general appearance. The way he carries his head-his attention to surrounding objects-his gait-and the lively motion of his ears, may all or each be looked to as indicative of "bottom" or willingness to work. 
It is only however in a private stable, or in tliat of a respectable dealer, that these criteria can be depended upon: for in a market-place, the animal is too much excited by the cracking of whips, and the too frequent application of them, to be judged of as regards his temper. Neither must the buyer be thrown off his guard by the animation which horses display at an auction, or on coming out of the stable of a petty dealer, for it is a fact which cannot be too well made known, that there are many unprincipled dealers who make it their business, before showing a horse, to "put some life in him," that is, they torture him with the lash, till, between pain and fear, the poor animal is so much excited as to bound from side to side with his utmost agility, at the least sound or movement of the bystanders. Such a wretched want of humanity cannot bo too severely censured, and I would neither buy nor recommend another to buy, from a man, who degrades himself by such abominable cruelty and. pitiful efforts to cheat his customer. However, I believe, most well-informed and respectable dealers have now done away with, and prohibited their grooms, from whipping as well as many other paltry and easily seen through attempts to 
impose upon the unwary. But the art of cheating still reigns triumphant in the stables of the unprincipled "coper," and the buyer should, if possible, shun him.

In considering the conformation of the horse, it is convenient to divide him into Head and Neck, Trunk or Carcase, and Extremities, or the Hind and Fore Legs. Under these heads, I shall note what are deemed the most essential points, and only those: for there can be no occasion for dilating upon the subject as is usual, when attention is directed to such trifles as, "the ears should be well placed, small, pointed, erect, covered with thin skin, the eyelids thin, the muzzle thin, and well supported," \&c. Such an account might consistently close by saying, that the horse should have four feet as well as four legs. Until men can make horses as they say they should be, the purchaser must content himself if he gets one with those qualities which are most important in fitting him for his destined work, and whose general appearance will do his master no discredit.

\section{The Head and Neck.}

The head, as being a part not at all contri- 
buting to progression, should, in the saddle horse, be small, that it may be light-the nostrils expanded to admit plenty of air, and the space between the branches of the lower jaw, called the channel, should be wide, that there may be plenty of room for the head of the windpipe. In the draught horse, a heavy head is not, as far as utility is concerned, an objection, for it enables him to throw some weight into the collar, and hence, excepting its ugliness, it is rather an advantage if he is used entirely for draught. But it makes the saddle horse bear heavy on the band of the rider, makes him liable to stumble, and, when placed at the end of a long neck, is apt to wear out the fore feet and legs by its great weight. The neck of the saddle horse should be thin, not too much arched, and rather short than long, for the same reason that the head should be light: and in the dranght horse, it may be thick, stallion-like, and sufficiently long to afford plenty of room for the collar, and for the same reason that the head may be large in this animal. The windpipe should be large, and standing well out from the neck, that the air may have an easy passage to and from the lungs. The horse used for both carrying and drawing, 
should have a head and neck neither too light nor too heavy. The advantage of a heavy head and neck to a draught horse, is illustrated by the practice of some carters putting a boy on the shoulder of a horse, when starting a load in deep ground. By enabling him to throw the boy' weight besides his own into the collar, it assists him materially.

The Trunk or Carcase.

That the saddle horse may be safe and have extensive action, it is necessary that the withers be high. This advantage is indicated by the horse standing well up before; and it is usual in showing a horse to exaggerate the height of the forehand, by making him stand with his fore feet on a somewhat elevated spot. A horse with low withers appears thick and cloddy about the shoulder. In the ass and mule, the withers are very low, and the shoulders very flat, and this is the reason why they are so unpleasant to ride, and why it is next to impossible to keep the saddle in its proper place without the aid of a erupper. High withers, however, are not essen- 
tial to the racer or the draught horse. The former does all his work by leaps, and that is performed best when the horse stands somewhat higher behind than before: neither are high withers necessary to the draught horse: but in the roadster they are as important as the safety of the rider is, for a horse with a low forehand is easily thrown on his knees. In the draught horse, this tendency towards the ground is obviated by the support the collar affords.

The chest should be deep and wide in all horses, but especially so in one intended for quick work, in order that there may be plenty of room for those important organs, the lungs. When the chest is deficient in capacity, the horse has neither strength nor endurance; and is in stable language termed "washy." Such horses have in general more fire than vigour, and being showy, may carry a lady well enough, but are comparatively worthless for effective service. A narrow chest is indicated by the fore legs standing close to each other.

The barrel behind the girth should approach as nearly as may be to a cylindrical form, that there may be plenty of room for the digestive organs. 
The back should not be too long nor too short, for though length is favourable to an extended stride and rapid motion, yet it makes the horse weak, and unable either to draw or carry any considerable weight. On the other hand, if the back be too short, the horse's action must be confined, and short-backed horses in general make an unpleasant noise when trotting, by striking the shoe of the hind foot against the shoe of the fore one: and though they are in general very hardy, and capable of enduring mucl fatigue, and of living on but little food, yet a back of middling length is better by far than one immoderately short or long.

The back should be nearly straight; when it is curved downwards, the horse is termed "saddlebacked," and though he is very easy to ride and pleasant in his pace, yet he is weak, and unable to carry a great weight. Sometimes, instead of being sunk, the spine is arched upwards, and the horse is said to be "roach backed." He is the very reverse of the saddle-backed horse in every respect.

The croup, or space between the termination of the loins and the root of the tail, should he considerable, and in a horse intended for quick 
work, it should run more in a horizontal than a perpendicular direction. In the Irish horse, this part is short, and instead of proceeding almost directly backwards, suddenly droops, and though such a conformation does not unfit him for trotting, or drawing, or even leaping, and is even an advantage for an upright leap, yet he cannot in the gallop compete with the English horse, whose croup is long, and very little inclined downwards.

The quarters are never too extensive from before backwards, nor deep from above downward, nor are they ever too much spread out laterally. A great deal is done by the hind legs, and the quarters should in every case be as expanded and well furnished with muscles as possible. When the haunch bone projects more than usual, the horse is said to be "ragged hipped," and is commonly objected to for it. But as this bone, by spreading well out, affords plenty of room for the attachment of muscles, it cannot be said to be a fault. When it appears so, the loins are the seat of that fault. They are too narrow.

The Fore Leg.

In the saddle horse, and where safety is desir. 
able, the position of the fore leg is worthy of attention. It should be placed well forward, and descend perpendicularly to the ground, the toe being nearly in a line with the point of the shoulder. The pasterns should neither be turned in nor out. When they are turned inwards, the horse is in general very liable to cut the fetlock joint by striking the opposite foot against it. The draught horse may be excused, though he leans a little orer his fore legs, but the saddle horse will be apt to stumble if he does so.

The shoulder should, like the hind quarter, be extensive, well covered with muscle, and in the saddle horse, where rapid and extensive action is required, it should slant from the withers to the breast. The neck should join the shoulder in such a manner as to seem to run into it. But the draught horse's shoulder should be, and usually is, more upright, that the collar may sit well upon it. The setting on of the neck is more distinct in the draught than in the saddle horse, the shoulder bone being more upright; and the muscles taking a different direction make the shoulder swell out abruptly, and form a seat upon which the collar conveniently rests.

The elbow should be wide from before back- 
wards-the space between it and the knee rather long, and well supplied with muscles-the knee should be broad from before backwards, and straight: when it is bent forward, the horse is said to be "bent before," and it is, in general, a symptom that he has endured some hard work, and his sure-footedness cannot be depended upon. When the knee is bent backwards, it is called a "calf knee," and though it is an ugly fault, I am not aware that it is any thing more, although it is possible there may be a little loss of power in the muscles that bend it. Below the knee the leg should be fine, and flat in back and front, and broad from before backwards. The back tendons should stand equally well out from the knee to the fetlock.

The pasterns in the very heavy draught horse, are, in general, short and nearly upright : and it is necessary that they should be so, in order to uphold his huge frame; but in the racer, they are long and slanting, in order that, by giving way at every step of the animal, the shock accompanying rapid motion may be destroyed. The purchaser must, therefore, look for a horse, whose pasterns have the proper degree of obliquity for the purpose the horse is to be used for. 
If the pastern be too long, the leg is very liable to strain, and eren the horse to break down when urged to the top of his speed. If it be too upright, the action of the horse is stilty, and very unpleasant to the rider. And besides that, such horses are, from the concussion they are liable to, very subject to diseases of the bones below the knee, such as ring bones, splints, \&cc.

The foot should be as nearly round as possible, smooth, and displaying no signs of brittleness by pieces being broken and chipped off by the nails; the sole should be but moderately concave; when flat, it is objectionable, and particularly so in the heary, high actioned horse, for there is then a probability, of its becoming convex.

\section{The Hind Leg.}

I have already spoken of the quarter. The part between the stifle and hock joint, commonly called the thigh, should be long, and, above all, supplied with abundance of muscle.

he hock should be broad from before backwards, because when it is so, it shows that a lever (the point of the hock) is long, and, consequently, 
the muscles that act upon it will have more power to extend the leg. And as it is by the extension of the leg that the animal is projected in the gallop and leap, it is of importance that the hock be broad, and the point projecting backward, in the horse wanted for quick work. The hock should likewrise in the same animal be well bent under him. When the hocks lean towards each other, the horse is said to be "cat hammed," or "cow hocked." It is most common in ponies ; but setting aside its ugliness, it is not a serious defect: indeed it is commonly thought to make the animal a good trotter. It is certain, that a hock bent outwards is more objectionable, for the weight of the carcase is then like a person placed between two stools. Below the hock, the back tendons and the pasterns should be the same as in the fore leg.

Short as this account of the conformation of the horse is, it might hare been still shorter, for it is a fact, that the existence of one good point is in general sufficient to ensure the possession or another or others. A good shoulder, for instance, rarely goes without good withers, a deep chest, and a well-turned fore leg: but as it sometimes does, I have briefly particularized all that is com- 
monly deemed most essential in the formation of a good useful horse. I must now proceed to speak of the proper method of examining him for disease. But first, a few words on the nature of soundness, unsoundness, and the laws relating to warranty.

Soundness.

At first view it seems easy enough to define a sound horse. It may be said that a horse is sound, when every part of him is in perfect health : but, upon further consideration, it will appear, that such a definition would be of little or no practical utility; for scarcely a seven year old in the kingdom could be fairly said to answer to it. The most trifling splent, or even a wart, no matter how small, or where placed, are deviations from health, and would make a horse unfit to be warranted, if such a definition of the term sound were to be adopted. It must therefore be qualified in order to be useful, and that the buyer and seller may be placed upon something like an equal footing. This, however, is not so easily done, for a horse is liable to several trifling dis- 
eases, which do not in the least incapacitate him; and yet it is difficult, I think I may almost say impossible, to define soundness in such a way as to admit those, without, at the same time, admitting others of greater consequence: and, on the other hand, it is as difficult to define unsoundness, so as to embrace all those diseases or faults which deteriorate the animal, without likewise including many that do not. Under such circumstances, a middle course is the most advisable, and though there must be some outstanding points, yet they are so seldom met with, that they may be left to the decision of the lawyer or the veterinary surgeon, according to circumstances. It is evident, however, that natural defects in the conformation, temper, or action of the animal must not be considered as unsoundnesses. There is difference of opinion and strife enough in horse-dealing already, and to introduce the doctrine, that a natural defect is an unsoundness, would not diminish it. Nothing but the existence of disease of one kind or another can in justice be so considered. I think the definition most likely to be generally useful, and most impartial to both buyer and seller, is this : -A horse is sound, when there is no disease 
about any part of him, that renders, or is likely in future to render him, less useful than he would be without it. And, of course, it horse must be unsound, when he has any disease about him, that renders, or is likely in future to render him, less useful than he would be withont it.

Before I proceed further, perhaps I had better explain what the word disease means; lest it prove as great a puzzler as unsoundness itself. It may be shortly stated to mean deviation from the healthy structure, or function, or both, of a part or the whole of the frame. Every part of an animal has a texture or structure peculiar to itself in health, and every part has its duty or function to perform; and every part is subject to alteration in structure, and interruption in function: and thus we have two kinds of disease. An example will illustrate this. It is the duty of the liver to make bile, to answer a certain purpose in the animal economy: but if the bile is made so deficient in quantity or quality as not to serve that purpose, then we say there is a functional disease of the liver. Again, if the liver be altered in bulk, or hardened or softened, or in any other way deviates from its natural and healthy texture, then we say there is organic 
disease of the liver. Every part of the body is liable to these two kinds of disease, and either may exist separately or combined in the same part. It is their union in an important part, that in general makes a horse unsound. Some veterinarians therefore say, that " alterations of structure, attended with interruption or impairment in function, constitute unsoundness." But I do not adopt such a definition, because, in my opinion, it is not sufficiently comprehensive on the one hand, and is too much so on the other. Of course, it excludes those diseases where altered function is not combined with altered texture, and hence several undoubted unsoundnesses are out of its reach, such as glass eyes, partial palsy, crib-biting, \&c., where there is no perceptible alteration in structure; and even mange, and some stages of glanders are not comprehended in it, because, though there may be, and generally is, alteration of structure united with impairment in function, yet a slight alteration in the function of the part where the disease is seated, does not in every case interfere with the horse's capability for work. Still these diseases constitute unsoundness: the one will sooner or later destroy the animal, while there is little chance of the 
other being cured, without the owner's losing some of the horse's service. A mangy horse cannot be used upon every occasion: his owner cannot with decency ride him in the field, neither can he harness him along with another horse without the risk of infecting him likewise. More might be said against this definition, and much against some at present adopted by eminent veterinarians: and, indeed, something may be urged against every definition of unsoundness that we can possibly frame. The only way of proceeding, is to use that which a majority would decide to be the most useful. Intercourse between experienced reterinarians has, till within these few years, been exceedingly limited, and hence advancement has not been so rapid as it could be wished. But the establishment of a useful periodical has done much, and will, by and by, do more. In the mean time, I think it is better, in defining unsoundness, to use disease, and let that word express deviation from healthy structure, or function, or both, of any part, or the whole of the body. Hoping I have spoken sufficiently plain on this head to be understood by non-professional men (for I wrote only for them,) I shall now proceed to the 


\section{Laws relating to Sale and Warranty.}

And as the following extract from the "Veterinarian," as quoted from the "Law Magazine" for October, 1828, comprises all that I can say upon the subject, I shall insert it as it stands.

"Lawsuits, it has been justly remarked, originate less frequently in the positive dishonesty and bad faith of the litigants, than in their gross misconception of each other's rights and liabilities. We therefore conceive, that an occasional purchaser, would often, by a very slight acquaintance with the first principles of the law of sales and warranties, be not only delivered from much anxiety in negotiating this awfully delicate bargain, but he also, in many instances, would escape the misery of being driven to contend for his rights in the dreaded arena of a court of justice. Our observations on warranty shall be preceded by a cursory view of the general contract of sale itself, in the course of which we shall select for our more particular notice, out of the multitude of rules by which this contract is more or less directly governed, a few that are marked by some degree either of difficulty or peculiarity in their 
application to our subject-matter, and a few others of primary importance, though not similarly distinguished; being compelled to a selection of some sort, by the obvious impossibility of even alluding, in the compass of a few pages, to a hundredth part of the incidents which ought to be treated of in a regular dissertation on this subject.

"A sale is defined by Blackstone to be 'a transmutation of property from one man to another, in consideration of some price or recompense in value.' But the terms of this definition, as the celebrated commentator immediately subjoins, are evidently too comprehensive, as they embrace the case of an exchange as well. A transmutation of property for a pecuniary consideration, seems, therefore, to be the proper definition of a sale. It is a transmutation of the right of property in goods, let it be remarked, as contradistinguished from the mere right of possession.

"To enable society to enforce the obligations resulting from such an engagement, some satisfactory remarks are obviously requisite, of the mutual consent of the contracting parties having existed in a serious and deliberate form. 
By the Statute of Frauds it is enacted, ' that no contract for the sale of any goods, wares, or merchandize, for the price of $£ 10$ or upwards, shall be allowed to be good, except the buyer shall accept part of the goods so sold, and actually receive the same, or give something in earnest to bind the bargain, or in part of payment; or that some note, or memorandum, in writing, of the said bargain, be made and signed by the parties to be charged by such contract, or their agents thereunto lawfully authorized."

In regard to Delivery and Acceptance.

"It is necessary to observe, that a manual transfer or actual delivery and acceptance is not in every case essential; for the law will often, from certain acts, imply a delivery to satisfy the statute. In the case, e. g., where the plaintiff, who kept a livery stable and dealt in horses, was in treaty with the defendant for the sale of two horses, and the defendant offered a less sum than was demanded, but at length sent word that ' the horses were his, but that, as he had neither servant nor stable, the plaintiff must keep them at livery for him.' The plaintiff, upon this, re- 
moved them out of his sale stable into another stable; and it was held that there was here a sufficient delivery to satisfy the statute. The key to this and similar cases, seems to be, that the vender, by the terms of the bargain, is converted into an agent for the vendee, and thus occupies the double character of principal during the sale and servant upon its completion. It is also sufficient evidence of a delivery, if a purchaser, with the privity and approbation of the vender, exercises any act of ownership over the goods, though their local situation remains unchanged; as by selling, (or even showing the animal out for sale) to a third person, or marking the animal in any manner. Delivery to a servant or agent, is equivalent to a delivery to the employer himself.

\section{In regard to Earnest.}

"It would seem, that giving a piece of money, however low its value, (supposing it to be 'altogether parted with,') is sufficient to bind the bargain.

In regard to any signed Note or Memorandum.

"It may be useful to observe, that, although 
the names of both parties must appear upon the face of the memorandum, or at least, in some writing capable of being connected therewith by sound legal inference, yet the signature of the party sought to be charged, or of his agent is sufficient; and this term, signature, be it observed, is not here used in the limited sense of subscription, so as to require the party to sign his name at the end of the instrument, but is equally applicable in whatever part the name is written. Whether sales by public auction are within the Statute of Frauds has long been a disputed point, the later opinion is in favour of their being so; and it therefore becomes necessary to mention here, that the auctioneer, is, in such sales, the agent of both parties.

"Upon the regular completion of the sale, the property in the article is transferred to, and absolutely vested in the vendee; and the purchaser, thenceforward, stands by all risks, and is the sole sufferer from any injury which may happen to the animal, otherwise than through the negligence of the vender. As in the example given by Blackstone: If $\mathbf{A}$ sells a horse to $\mathbf{B}$ for $£ 10$, and $B$ pays him earnest, or signs a note in writing of the bargain, and afterwards, before the 
delivery of the horse or money paid, the horse dies in the vender's custody, still he is entitled to the money, because by the contract the property is in the vendee.

But, although the right of property is thus absolutely transferred by the contract, yet, unless payment be expressly postponed to a future day, the buyer will not be entitled to possession, without tendering the stipulated price.*

\section{Warranty.}

"We now come to the important doctrine of Warranty, which is thus summed up by Lord

* The principles of the Law of Scotland, in regard to the constitution of the contract of sale, differ considerably from those of the Law of England, as stated in the preceding paragraphs. There is no statutory enactment in Scotland similar to the statute of fraud in England, and matters are left to be ruled by the common law, according to which, the contract or bargain is fully completed so as to prevent resiling, without either earnest, delivery, or note of sale. But although a simple verbal bargain is thus binding on the parties, so that neither can draw back, the other being willing and able to perform his part, the property of the thing sold is not passed without delivery, contrary to the English rule, which holds the property to have passed immediately on the bargain being completed. The practical result, however, of the two laws, as to this last-mentioned particular, is nearly the same, as the rules in England as to the right to obtain possession, place matters on almost the same footing as the principle of the Law of Scotland as to the property not being passed till delivery. 
Coke. 'By the civil law, every person is bound to warrant the thing that he sells or conveys, although there is no express warranty; but the common law binds him not, unless there be a warranty either in deed or in law, for caveat emptor; the meaning of which Latin expression is, that the buyer takes the article sold, with all its defects, and must not look to the law for any redress, if its intrinsic worth do not correspond with its outward appearance. It cautions the buyer, therefore, according to the Italian proverb, that he has need of a hundred eyes, but the seller of only one." "

"By the law of England, warranties are divided into express or implied; the latter, however, differ in no respect from the former, except in the circumstance of proof. The intention to warrant, is collected from the whole tissue of circumstances proved, and as a legitimate deduction from them, like the presumption of any other part not established by direct evidence : while the express warranty is proved by direct and express testimony to the fact itself. To give a single instance: In Jones $v$. Bowden, it was proved to be the uniform course and habit of dealing in a particular place, if the article were 
sea-damaged, to state that fact on the sale of it; a sale was made without any such statment, and it was therefore held that the article was warranted not sea-damaged. This was an implied warranty."*

"A warranty can only exist as a term and condition of the contract of sale, into the very essence of which it so completely enters, that a breach of it entitles the buyer to treat, if he pleases, the whole contract as a nullity. It constitutes part of the inducement or consideration for the purchase. It follows that, for a warranty to be valid, it must exist or be made at the time of the sale; or at least, that, being agreed to be made before, there should be an understood

* In Scotland, warranty, or warrandice as it is termed in Scotch law phraseology, is always implied in the contract of sale, (unless, perhaps, excluded by the special practice of particular trades, ) and therefore if the seller intend not to warrant, this must be expressly stipulated in the contract. The warrandice thus implied in all contracts of sale extends not only to the soundness of the animal sold, and its being free from vice, but also to its fitness for the special purposes for which it has been sold, when that purpose has been specified in the bargain; and, if two horses have been sold as a pair, even although not for running together in harness, if one of them should prove unsound or unfit, so as to authorize his being returned, the purchaser will be entitled to return both. 
reference at the actual sale to that agreement. As for instance, if, previous to the time of sale, the vender says he will warrant the goods, and having named his price, gives the vendee two or three days to consider of it, and the vender then agrees to purchase, the warranty, though only made hypothetically, is tacitly incorporated into the terms of the sale, and is a valid warranty.

"But a warranty made after the completion of the sale is of no value whatever, being without any consideration.

"From these premises also, coupled with the rule, that where a contract is reduced to writing, the writing is the sole legitimate evidence to prove its terms, we may further deduce, that an oral warranty made previously to a sale by written contract, but not inserted in the instrument, will not be valid. Thus in Pickering $v$. Dowson, Gibbs, C. J., says, ' I hold that if a man brings me a horse, and makes any representation whatever of his quality and soundness, and afterwards we agree in writing for the purchase of the horse, that shortens and corrects the representations; and whatever terms are not contained in the contract do not bind the seller, and must be struck out of the case.'" 
"It is also a rule of law, that where a cons. mission is given to execute any work, every power necessary to carry it on will be implied. A servant, therefore, employed to sell a horse, has an implied authority to warrant that it is sound; and in the case of a general agent-for example, the servant of a livery-stable keeperthis warranty will bind the master though made conirary to his express directions; and in every case, the warranty of a servant or agent, so intrusted to sell, will bind the principal, if he do not expressly prohibit it being made.

"With respect to what declarations of the seller will amount to a warranty, the primary rule for the interpretation of contracts in general is applicable. It depends upon the intention of the parties.

"Thus a simple affirmation of the goodness of an article is a warranty, provided it appear to have been so intended; whereas the sublimest epithets that seller ever employed to recommend his goods to a credulous buyer, will be regarded as the idle phraseology of the market, unless an intention to zarrant actually appear. For example, when the vender declared at the time of sale, that he could warrant, it was heid to mean 
that he would and did warrant. So when the seller affirms that the goods are his property, he is held to warrant the title. And, on the other hand, when at the time of sale the seller showed the buyer a written pedigree, which he had received from the person of whom he bonght the lorse, and said he sold him according to that pedigree, the mark being out of his mouth when he bought him, and the pedigree was proved to be false; it was held that this was no warranty. No general rule, therefore, can be laid down on the present head, further than this-that it is from the intention of the parties, as collected from the whole transaction, and from the meaning they appear to afford to particular expressions, that the existence or non-existence of a warranty is to be inferred.

"But the most important part of our investigation relates to the extent of the warranty. We must here observe, in the first place, that although a warranty may be made to extend to temper, freedom from blemish, age, aptitude for particular work, and many other similar qualities, as well as to soundness; yet unless expressly so extended, it will be construed to apply to soundness alone. Thus, when an ambiguity arose from 
the insular position of the word 'warranted' in the following notice: 'To be sold, a black gelding, five years old; has been constantly driven in the plough-warranted,' the warranty was held to apply to soundness alone.

"Unsoundness is a term the exact limits of which are not very clearly defined. According to Lord Ellenborough, any infirmity which renders a horse less fit for present use or convenience, is an unsoundness. This doctrine was laid down by his lordship in a case which turned upon an alleged lameness, and wherein it was admitted by a witness for the defendant, that one of the fore legs had been bandaged, becanse it was weaker than the other: upon this admission, the verdict in favour of the plaintiff seems to have been founded: and it was then observed by the court to constitute unsoundness, it is not essential that the infirmity should be of a permanent nature; it is sufficient if it render the animal for the time unfit for service; as for instance, a cough, which renders it for the time less useful, and may ultimately prove fatal. Now this decision appears to contradict a prior one, in which Eyre, C. J., held, that a slight lameness occasioned by the horse having taken up a nail 
at the farrier's was not an unsoundness. This learned judge, in his observations to his jury, remarks -' a horse labouring under a temporary injury or hurt, which is capable of being speedily cured or removed, is not for that an unsound horse within the meaning of the warranty.' If these decisions are not to be regarded as conflicting, one deduction ought possibly to be, that such slight injuries as proceed from external causes, and are with moral certainty to be speedily and effectually cured, do not fall under the head of infirmities, which term properly comprehends such diseases only as may without much improbability hang by the animal through life, while they impair his present usefulness.

"Crib-biting, in its incipient state, has been held to be no unsoundness; but, when inveterate, (and interfering with the health of the animal,) it then falls within the meaning of the term.

"It is commonly asserted that a warranty will not bind when it is obviously false; the instance given being that of a horse warranted sound, when it is apparent that he is blind; and for this doctrine, the venerable argument, which makes so conspicuous a figure in legal logic, is usually urged-for that it is his own folly. For 
that it is the other's roguery, might, we think, be an argument of greater cogency the other way, unless knaves in this country are to be regarded with peculiar favour, like idiots in Turkey; but we apprehend that this rule, if any such indeed exist, is one of presumption only, it being inferred that both parties meant to exclude the particular defect from the warranty. The case of Shillitœ $v$. Claridge, however, goes far towards disproving the existence of such a rule.*

"Let us now consider how the rights of the parties are affected by the horse being unsound

"Shillite $v$. Claridge, where the horse had a cough at the time of the sale, it appeared that he had been bled for it before he was sold, and there was no evidence of any mismanagement by the buyer; and it appeared he was told that the horse had a cough, and was used only to the road, and that he had sent him to the hunt. Lord Ellenborough: "If it had the cough, and it was of a permanent nature, I have always held that it was a breach of the warranty; and such has, I believe, been the understanding both in the profession and amongst veterinary surgeons. On that understanding I have always acted, and think it quite right. Knowledge makes no difference. There was a case before Mr. J. Lawrence in which it was held, and it was there said, that the plaintiff might rely upon the warranty only, and not choose to trust to his own knowledge. I have always understood that a cough is an unsoundness; the horse then was unsound when he was bought, and there was no proof of any discontinuance of that unsoundness, or that he would have got well if he had not been hunted." " 
at the time of warranty. The contract being thus broken on the part of the seller, it is at the buyer's option either to treat it as a nullity, and return the horse, or to retain him notwithstanding, and bring an action on the warranty.* In the former case, the price paid is the measure of damages, which he will be entitled to recover in an action; in the latter, the difference between that price and his real value. If he offer to rescind the contract, and return the horse, he may also recover the expenses of his keep; but in order to this, a positive tender is said to be necessary. $\uparrow$ No notice of the unsoundness need be given to the vender to entitle the vendee to maintain the action; nor is it necessary to bring

* In Scotland the purchaser cannot retain the horse and bring an action to recover the difference between the price and the real value. He must either keep him at the price at which he has bought him, or return him on getting repayment, and if he have further suffered direct damage from the unsoundness, \&c., of the horse, he will also have an action of damages for reparation.

+ As in the case of Caswell $v$. Coare, "where upon breach of the warranty proved, but no tender made of returning the horse, it was objected that plaintiff could recover nothing for the keep. Lord Mansfield : 'The contract being broken, the defendant must give back the money, and the plaintiff must return the horse; but unless he has previously tendered him, he cannot recover for the keep, because it was not the defendant's fault that the plaintiff kept him.' " 
the action immediately on discovering the unsoundness."*

- As in the case of Fielder $v$. Starkin, where an action was brought "on the warranty of a mare, "that she was sound, quiet, and free from vice and blemish.' Soon after the sale, the plaintiff discovered that she was unsound and vicious; viz., a roarer, had a thorough pin through the hock, and had a swelled hock from kicking; but kept her three months, and gave her physic, and used other means to cure her; at which time he sold her, but had her soon after returned as unsound, when he returned her to the defendant as unsound, who refused to receive her. On her way back she died; and upon being examined, it was the opinion of the farriers that she had been unsound a full twelvemonth before her death; but it did not appear that the plaintiff had ever in the interval, though in the defendant's company, complained of the mare being unsound. Lord Loughborough :- 'Where there is an express warranty, the warranter undertakes that it is true at the time of making it. If a horse which is warranted sound at the time of sale, be proved to have been at that time unsound, it is not necessary that he should be returned to the seller. No length of time elapsed after the sale will alter the nature of a contract originally false, neither is notice necessary to be given; though the not giving notice will be a strong presumption against the buyer that the horse at the time of sale had not the defect complained of, and will make the proof on his part much more difficult. The bargain is complete; and if fraudulent on the part of the seller, he will be liable to the buyer in damages, without either a return or notice. If, on account of a horse warranted sound, the buyer should sell him again at a loss, an action might perhaps be sustained against the orignal seller, to recover the difference of the price. In the present case, it appears, from the evidence of the farriers who saw the mare opened, that she must have 
"But although such notice be not essential, yet it is always advisable to be given, as the omitting to do so will furnish at the trial a strong presumption that the horse, at the time of sale, was free from the defect complained of, thus rendering the proof of a breach of warranty more difficult. Common justice and honesty, it has been remarked, require that the commodity should be returned at the earliest period, and before it has been so changed by lapse of time, as to make it impossible to ascertain, by proper tests, what were its original qualities.*

been unsound at the time of the sale to the plaintiff." Plaintiff recovered the full price.

The principle of the Law of Scotland is very different from this; a purchaser is bound so soon as he discovers a defect, to give notice to the seller, and offer to return him, and if he neglect this, he will be held to have acquiesced, and will be barred from afterwards throwing him back on the seller. The exact time after coming to the knowledge of the defect, within which the purchaser must offer to return, has never been precisely fixed, but there must be no undue delay, and the sooner a purchaser gives notice the better.

* As in the case of Curtis $v$. Hannay, " where, after the sale of a horse warranted, the purchaser was informed of a defect in the eyes; but he kept him for nearly seven weeks, in which time, suspecting the horse to have some defect in his feet, he had applied a blister and other medicines, which 


\section{To entitle the buye: to the benefit of the} warranty, he must, of course, strictly fulfil the

produced thrush and a considerable degree of lameness; it was, however, only temporary ; and it was in evidence, that the remedies applied to the feet could not have affected the eyes. Lord Eldon thought the matter set up by the defendant no answer to the action. "The question was, would the horse, when returned to the seller, be diminished in value by this doctoring? If he would, he thought the defendant should pay the price, and bring his action against the seller for any defect in the warranty existing at the timo of the sale. He took it to be clear law, that if a person purchased a horse which is warranter, and it afterwards turns out that the horse was unsound at the time of the warranty, the buyer, might, if he pleased, keep the horse, and bring an action on the warranty, in which he would have a right to recover the difference between the value of a sound horse and one with such defects as existed at the time of the warranty, or he might return the horse, and bring an action to recover the full money paid; but in the latter case, the seller had a right to expect that the horse should be returned in the same state he was in when solll. and not by any means diminished in value; for if a person keeps a warranted article for any length of time after discovering its defects, and when he returns it, it is in a worse state than it would have been if returned immediately after such discovery, the party can have no defence to an action for the price of the article, on the ground of non-compliance with the warranty, but must be left to his action on the warranty to recover the difference in the value of the article warranted, and its actual value when sold.' His Lordship directed to find for the price of the horse, if they thought that by such blistering and doctoring the animal was not diminished in value to a future purchaser ; and they found accordingly." 
conditions stipulated to be performed on his part. Thus if, as is frequently the case, a condition be introduced into the warranty, that the horse, if objected to as unsound, shall be returned within a limited time, no action can be maintained for the unsoundness without the strict performance of this condition. So where the warranty was qualified by the vender by an undertaking to take back the horse, if, on trial, he should be found to have any of the defects mentioned in the warranty, it was held, that the buyer must return the horse immediately on the discovery of them. When the contract is rescinded by the buyer on aecount of the warranty being broken, the seller has a right to require that the horse shall be returned in as good condition as he was when the defect was discovered; and therefore, if the animal fall into a worse state subsequently to such discovery, the buyer cannot then return him, but must rely on his action to recover back a proportional part of the price.

"There being no warranty, but the purchaser having been imposed upon, and entrapped into a losing bargain by the artifices and wilful misrepresentations of the seller, his remedy is an action for the deceit; to support which he 
must prove a fraud to have been committed by the seller, and also that it was such as might well impose upon a person of ordinary circumspection; or, in other words, that he was deceived and misled by relying upon the integrity of the seller, in a point where he might reasonably have placed trust and confidence in him.

"Any wilful misrepresentations by the vender, of the qualities of the commodity to be sold, whereby the vendee is induced to purchase, falls within the legal idea of fraud, and will vitiate the contract; as being a breach of that good faith which ought to reign throughout every commercial transaction. This may be called fraud in words. Thus if A, knowing his horse to be brokenwinded or lame, induce $B$ to purchase, by an assurance that he is sound in wind and limb, then although A may have expressly refused to warrant, $B$ will nevertheless be entitled to recover from $A$ in an action for the deceit. It is obvious, however, that this action could not be here maintained upon mere proof of the abstract falseness of the representation made by the seller; but that evidence of the moral falsehood is requisite-the seller's knowledge of the falsity, that is called, in technical language, the scienter. 
And herein it is, principally, that this action is distinguished from actions on breach of warranty; for the warranty extends to all faults, known or unknown to the seller.

" The other kind of fraud may be termed fraud in deed; and we shall conclude this article by producing an instance which may serve to exemplify the nature of those acts of the seller, which would fall under this head, 'I remember,' says Gibbs, C. J,, 'the case of the sale of a house in South Audley Square, where the seller, being conscious of a defect in the main wall, plastered it up, and papered it over; and it was held that, as the vender had expressly concealed it, the purchaser might recover.' To extend this principle to our subject-matter:-it is conceived if the vender were to deceive the purchaser, either as to colour, which may be easily done by chemical means, or as to age, by (to use a west-country phrase) bishopping the animal, he would be liable for the deceit, although no verbal representations had been made."*

* "If the vender knew the goods to be unsound, and hath used any art to disguise them, or if they are in any shape different from what he represents them to be to the buyer, this artifice shall be equivalent to an express warranty, and the vender is answerable for their goodness." - Blackstone's Commentaries. 
The warranty is generally included in the receipt for the purchase money, and should run thus :

"Glasgow, August 3d, 1833.

Received from A. B. the sum of thirty pounds sterling for a Bay Gelding, warranted Sound and free from Vice.

$$
\text { £30. C. D." }
$$

The animal's temper and abilities may also be included, if the purchaser thinks proper. As " warranted sound, free from vice, quiet to ride and drive, and a good leaper." Vice should always be included, for a vicious horse is often a worse bargain than an unsound one. And as there is little probability of vice being discovered by the purchaser prior to sale, unless a trial be obtained and opportunity afforded of displaying it, it is so much the more necessary that it should be guarded against by the warranty.

A qualified warranty is one, in which the horse is warranted sound, with the exception of something pointed out at the time of sale, and mentioned in the warranty: as for instance, "warranted sound, excepting some tenderness of the off fore foot." In this case, the horse cannot be returned, though the lameness should turn 
out to be greater than the purchaser expected, unless it can be proved that the seller took some means to hide its real nature, as he might, and sometimes does, by making the horse tender on the sound foot.

With regard to vice, I would say a horse is not free from it, when he has any thing in his temper or habits that makes him more difficult to manage, either in the stable or at work, than he would be without it: and consequently, I consider a horse warranted free from vice, returnable, if he turn out a kicker, biter, rearer, dangerous to shoe or clean, guilty of shying, running away, or of being dangerously or annoyingly restive in any way. It is not always easy, however, to return a horse for any of these faults, for, even though he may have been warranted free from them, it is very difficult, often impossible, to prove that he possessed them before he changed masters.

The purchaser, after selecting an animal, whose height, form, age, and action, are most suitably adapted for the work, will next proceed to examine him for diseases that do, or are likely to, make him less serviceable,

This scrutinizing process will be much sooner, 
much better and more completely performed, by proceeding in a systematic manner. Very rarely indeed does a buyer pursue any method in examining a horse. Even the majority of dealers do nothing but look at the foot, back tendons, teeth, give the horse a punch in the ribs-and all is over: and then he takes npon him to warrant the horse sound. The following Table is an enumeration of the parts to be examined, and the diseases most frequently found in those parts. The order in which they stand, is that in which I regard them myself, when examining a warranted horse.

\section{I.-The Head and Neck.}

1. The Eyes, for Cataract, Glass eyes, and specks.

2. The Nostrils, for Glanders, Tumours, and cold.

3. The Glands between the branches of the lower jaw, for Enlargement.

4. The Throat, for mark of Crib-biting strap, and the tenderness which accompanies cold.

5. The Teeth, for the Age, and marks o: Crib-biting.

6. The Veins of the Neck. See that both are entire 


\section{II. - The Foreleg and Shoulder.}

1. The Seat of the Collar, for tumours.

2. The point of the Elbow, for tumours.

3. The Knee, for blemishes, and stiffness of that joint.

4. The Shank, for Speedy cut, Splent, and Strain.

5. The Fetlock Joint, for Enlargement, Windgalls, Unnerving, and marks of Cutting.

6. The Pastern for Ring bone.

$$
\text { III.-The Foot for }
$$

1. Sidebones,

2. Sand crack,

3. Contraction,

4. Thrush,

5. Corns,

6. Flat Soles.

7. The Shoe, for signs of Cutting.

IV.-The Trunk and Quarters.

1. Each side of the chest, for marks of blisters and rowels.

2. The space between the fore legs, for the same.

3. The Hip bones. See that both are equally prominent.

4. The Stifle for Enlargement.

5. The Groin for rupture. 


\section{V.- The Hiock.}

1. Capped Hock.

2. Curb.

3. Thorough pin.

4. Bone Spavin.

5. Bog Spavin.

No blood Spavin.

Now let the horse be trotted, to see whether or not he is free from

1. Lameness,

2. The effects of founder,

3. String Halt,

4. Weak Loins.

Then the horse should be mounted, and ridden a few hundred yards at a gallop in order to quicken his breathing, and thereby display the presence or absence of

1. Roaring, wheezing, thick wind, \&c.

2. Broken wind.

This brief summary will assist the memory, bringing as it does the seat and causes of unsoundness into one point of view. It includes however, some objectionables, which, properly speaking, do not constitute unsoundness; such 
as windgalls, thorough pin, capped hock, and stringhalt. The first two are objectionable, as indicating that the horse has been severely exerted, and may be otherwise more seriously injured. The last two are eye-sores, and only to be avoided as such. This will appear more clearly presently.

I must now consider in detail, the different diseases enumerated in the above Table. The method of detecting them, must, in the first place, be pointed out; then those which constitute unsoundness must be distinguished from those that do not, and it will be proper now and then to mention, how far a horse may be useful, admitting that he have one, or even two diseases, that are unsoundnesses. In giving directions however, for discovering unsoundnesses, I can only go a certain length, for some of them require anatomical knowledge on the part of the examiner, in order to discover their existence : and even the possession of that advantage is not at all times sufficient to enable him to give a decided opinion, I shall endeavour, however, to make myself as clearly understood, as the nature of the subject will admit of. 
The Head and Neck.

The Eyes. Examination of the eye for cataract, illustrates what I have just said on the necessity of possessing an anatomical knowledge of parts. Cataract is a deep seated disease of the eye, which often exists in such a trifling degree, as, in many cases, to escape the scrutiny of the most careful veterinarian. At first it is a small white speck, situated at the bottom, not on the transparent surface of the eye; and this almost invariably increases in size, till it produces complete blindness; and a white ball, spotted with black, is then perceived, occupying a large portion of the interior of the eye. Long before total blindness takes place, the disease is visible to the most common observer, and the horse is said to have "Buck eyes." In its earlier stages, it is best observed in the shade, for then the pupil enlarges, and gives you a fuller view of the bottom of the eye; when it exists, a small milk-white spot is seen, whitest and brightest in the centre, the crrcumference of which passes gradually into transparency. Care must be taken, 
however, that this appearance be not produced by the reflection of some external body opposed to the eye. A white hat, or neckcloth, or a white wall, for example, would produce an appearance which a non-professional man might very readily mistake for disease. To prevent such a blunder, place the crown of your hat (if a black one) opposite the eye, and observe if the white mark disappears, which it will, if merely a reflection.

Cataract, in all its stages, renders a horse unsound. Even when very small, vision is imperfect, and the horse is very apt to shy. But the worst of it is, it goes on, in nine cases out of ten, till total blindness is the result : and it requires no great strength of reasoning to show, that a blind horse is not so useful as a perfect one. When the horse is destined to work with a companion, as in a stage-coach, where the road is clear, and the work done by day, a blind eye is beyond comparison, a less evil than a permanently lame leg. But a horse blind of botheyes is almost useless as a roadster, totally so as a hunter, and all but so for a carrier's cart. So that it will depend upon the price asked for the animal, and the work he is wanted for, whether 
the purchaser will reject or receive a horse partially or totally blind.

Gutta serena, or Glass Eyes, is a disease in which the horse is quite blind, without any apparent alteration in the structure of the eye. The optic nerve is palsied, and insensible to the rays of light. When it exists in both eyes, the general appearance of the horse will at once point out his lamentable condition-the rapid motion of the ears-the high, yet cautious action of the forelegs - and the extreme readiness with which the animal yields to the least movement of the bit.

When only one eye is affected with Gutta serena, it may be discovered by observing what is ealled the pupil-the opening in the centre of the darkcoloured part of the eyes. It will be found to be considerably larger than the opening in the living eye, and that opening does not contract when the eye is opposed to a strong light. In the other it does, and its contraction and delatation is sufficient evidence of the optic nerve being in health.

Gutta serena is unsoundness; but as it may have come on in an instant, and consequently it 
is impossible for a Veterinarian Surgeon to say that it existed prior to sale, it behoves the purchaser to guard well against it himself.

What I have said of the usefulness of a horse with cataract is equally applicable here, with this exception, that as it often proceeds from a disease of the brain, there is a possibility, a probability, of its sooner or later ending fatally, and that more especially if the horse is put to quick larness work.

Specks on the external transparent part of the eye are evident to all. They are generally produced by mechanical injuries, and do not constitute unsoundness. There is every chance of them disappearing of themselves, while there is none of their increasing in magnitude.

The Nostrils.

Few men have sufficient hardihood to offer a glandered horse for sale, yet there have been cases, where, after hiding all the symptoms, a gìndered horse has been thrown into the hands of a simpleton; so that there can be no harm in looking for the symptoms in every case : but in 
a crowded market, where all sorts of characters make their appearance, and some rascals too, make a very specious appearance, it is very necessary to guard against every thing, however improbable it may seem.

In Glanders, there will be a discharge from the nose; but that will be either hidden by the frequent application of a handkerchief, or, as is oftenest the case, before coming in to the market, the horse gets a gallop to clear his nostrils, an astringent wash is injected, and then a piece of sponge is forced up, so as to retain the matter. In such cases however, there is almost invariably some abrasion, or eating in, on the red surface, which covers the partition between the nostrils, and this may be seen by bringing the horse's head to the sun, and expanding the nostril, so as to get as high a view as possible. If there be any sore, reject the horse.

A plug in the nose may be very readily discovered, by shutting first one nostril, and then the other, so as to compel the animal to breathe through one at a time, which of course he cannot do, if any thing obstruct one of them while you shut the other. This will also serve to assure you that the horse is free from a tumour which 
sometimes grows in it, and by gradually increasing blocks it up. It is termed a Polypus, in Surgery, and constitutes unsoundness : as I need scarcely add, so does Glanders.

Horses, in travelling to a fair, or from the country to a dealer's stables in town, are very apt to catch cold on the way, and have discharge from the nose and soreness of throat. This the purchaser should guard against, for such cases frequently end very unfavourably; and indeed if the horse were treated as if he were well, he might probably take inflamed lungs and die. Such things are of frequent occurrence, and circumspection is therefore requisite. A thin watery discharge from the nose, and that small in quantity, is a symptom of this cold; and upon pressing the throat a little, the animal winces, evidently from pain : many horses, however, are purchased with colds, and no ill consequences ensue; but if the purchaser chooses to run the risk, he should not by any means use the horse as if he were perfectly well. A few days' rest in a well ventilated stable, mash diet, and some liquid blister to the throat, will, in a great many cases entirely remove a cold; while exertion, and re-exposure to the causes that first produced 
it, will most surely aggravate it, and perhaps induce a much worse disease. A special warranty may be obtained, making the seller responsible for the cold ; but to take that, and use the horse as if he were in health, would manifestly be taking an unfair advantage of the seller's ignorance: to say nothing of the inhumanity of working a sick horse.

A cough more or less frequent, always accompanies soreness of the throat, but it is not a disease of itself ; and, therefore, need not be spoken of as one. Some horses have a cough for years, and yet do their work, and maintain their condition, as perfectly, as if they had no such thing. The cough is barsh, dry, and most frequent directly after feeding or drinking, or just when the horse is taken into the open air. It is called chronic cough, and though the horse's health remains unaffected by it, yet it very much annoys him, and is exceedingly unpleasant to those who hear it. It cannot be discovered prior to purchase, nor can the purchaser be assured that it is not a symptom of common cold, until its continuance, unabated by the ordinary remedies, shows its real nature.

Chronic cough is generally considered an 
unsoundness, on the ground that it makes the horse more susceptible of the evils arising from sudden changes of temperature. I can only say, that I never observed this susceptibility. The purchaser, however, would do well to take a Veterinary Surgeon's opinion on the case before he makes up his mind to keep a horse with chronic cough, for it is frequently a symptom of diseased lungs, \&c.

If the glands between the bones of the lower jaw are swelled, it will most certainly prevent you from buying from a stranger or a reputed rogue: and in all cases, it will induce you to pay much attention to the nostrils; for this enlargement is one of the symptoms of glanders; but it likewise sometimes exists as a remnant of Strangles, and is then not at all prejudicial.

If the neck at its junction with the head, be out of proportion small, it is probable that that smallness has been produced by the use of a tight strap, to prevent crib-biting: and the teeth should be examined to see if they are much worn away, and chipped on their outer edge, which they always are when the horse is an old crib-biter: and his neck will not show any trace of the crib-biting strap, till he is an old one. 
Except the smallness of the neck, and the worn state of the teeth, I know of no symptom by which crib-biting may be discovered, until the animal has an opportunity, and is inclined to show it, as he does by seizing the manger, bending his head in towards his chest, and swallowing air, at the same time making a grunting sort of noise.

The nature of this objectionable point in the horse, has not yet been precisely ascertained; and hence much dispute has arisen, whether it be a vice or an unsoundness, or whether it be the product of disease, or of an imitative disposition. The following quotation from the Veterinarian, will show what a difference of opinion exists on this point, even amongst professional men.

"Paul v. Hardwick. This was an action on the warranty of a horse sold by the defendant, a horse dealer in Tottenham-court road, to the plaintiff, Mr. Paul the banker, in July last.

"The warranty was contained in the receipt given by the defendant for the price of the horse, and wasin these terms:- ' Received of J. B. Paul, Esq., the sum of sixty-five pounds, for a bay gelding, warranted sound, and free from vice.' 
The alleged unsoundness or vice was, that the horse was a crib-biter.

"Sir James Scarlet, in opening the case for the plaintiff, read an extract from Dr. Rees's Cyclopædia, in which crib-biting was described as a vice, and the writer, distinguishing vice from unsoundness, gave it as his opinion, on the effect of a warranty, that if it extended to soundness only, the horse was not returnable for crib-biting, but if it included a warranty against vice, it was ; crib-biting being, it was said, 'one of the worst vices.'

"Philip Hearn, who had had the care of the horse after the plaintiff purchased it, stated, that as soon as it was put into the stables, it began crib-biting pretty sharply, and mauled the harness about.

"Did you put the harness out of its way? O yes, or it would have been soon all gone.

"Did he appear to be an old crib-biter? Yes, he was a stanch old hand.

"It was proved that the defendant had had notice to take the horse back; and that he refused, stating that crib-biting was no 'vice.' He admitted that he knew the horse was a crib-biter at the time he sold it to the plaintiff. 
"The plaintiff's attorney said he believed it was the same horse that had been offered to him for $£ 30$, about six weeks before. It was a goodshaped horse, and in very fair condition; but he returned it because it was a crib-biter.

"Richard Tattersall, proved that the horse was sold at his father's auction, by the plaintiff's direction, on the 12th of July last, at 26 guineas. It was knocked down in the name of Robinson; but the defendant was present at the sale, and paid the money. The net proceeds were $£ 23$ : $19: 6$ d.

"[ It appeared by the subsequent evidence, that the defendant having got the horse again, afterwards sold it to the Rev. Dr. Halcomb.]

"Mr. Sewell stated, that he was assistant professor of the Veterinary College. Crib-biting, which was a vicious habit in horses, was considered as an unsoundness. It was treated as a disease. It frequently led to indigestion, and then, of course, there was no saying what might follow. It was curable in its early stages.

"Mr. Bracy Clark was of opinion, that cribbiting was one of the worst vices of a horse. It had always been considered as a vice. When it became confirmed, so as to affect the health of 
the animal, it was an unsoundness. A erib-biter, he should say, would be returnable upon a warranty against vice, but not upon a warranty confined to unsoundness, unless the health of the horse was affected by the habit at the time.

"The Attorney General addressed the Jury for the defendant, and called the following witnesses :-

"William Cadman stated, that he was in the employment of Mr. Shackwell, who kept stables in Oxford-street, for the sale of horses on commission. The horse in question (he believed it was the same) stood in those stables for sale in June last, and was purchased by the defendant. It was then very healthy, and in good condition. It was not a 'stanch old hand' at crib-biting: it bit but very slightly.

"Cross-examined.-Young horses would frequently imitate stanch old crib-biters.

"Richard Hardwick, the defendant's brother, stated, that the defendant bought the horse of Mr. Shackwell, in June last, for 40 guineas. It was warranted sound, and quiet to ride or drive. It was fresh, and in good condition; and continued so, till it was sold to the plaintiff. It was not a 'determined' crib-biter. It was kept 
in the defendant's stables, for a month before it was sold to the plaintiff, and the manger (a wooden one) was not at all injured by its biting.

“ Cross-examined. It had been since sold to Dr. Halcomb. The price asked was 60 guineas; but witness did not know what his brother got of Dr. Halcomb for it.

"Professor Coleman stated, that horses had the habit of crib-biting in very different degrees. He was inclined to think that the true meaning of the word 'vice,' was some vicious quality which was dangerous to the owner of the horse, or to others who rode or drove it, and not merely a defect or fault, because, if that were the case, tripping or shying would be a vice, and few horses were free from some defect or fault. A crib-biter might be a vicious horse, but not necessarily so because he was a crib-biter.

"Is crib-biting an unsoundness?

"That depends on the definition of the word unsoundness. I have always considered wherever there is an alteration of the function in any part, so as to influence the entire functions, and prevent the animal from performing the common du ties of a horse, that he is unsound. According to that definition, a crib-biter may or may not 
be unsound, If the habit exists in a slight degree-that is, if the horse only occasionally bites his crib, but supports his condition, and can perform all the duties of a horse, then I should say he was not unsound.

"On his cross-examination, the witness stated that the habit of crib-biting frequently produced a disordered function, which was the effect of swallowing the air in the attempt to lay hold of some fixed object. That produced indigestion and a disordered stomach, a difficulty of breathing, with spasms and inflammation; and if the disorder got lower down, it produced a disorder of the bowels. The habit of crib-biting might be acquired from imitating other horses; but that was by no means the most frequent cause. It frequently attached to high-bred horses, and others that were kept long without food. In ninety-nine cases out of a hundred that was the main cause of crib-biting. As the horse in question had been stated to be in good condition, witness should infer that none of its functions were impaired, and its health was not affected by this habit; and his opinion was, that, in gexeral, crib-biting did not affect the health of the animal. 
"Sir J. Scarlett.-Don't you know that cribbiters are always draughted from a regiment.

"Witness.-Not unless they have some other defect besides crib-biting.

"Re-examined.-Crib-biting did not arise from impaired functions in the animal, though it sometimes produced that effect.

"Lord Tenterden.-Suppose a crib-biter sold to-day in good condition, in six months hence it is found to have inflammation in the stomach or bowels, with a difficulty of breathing, or any of the other symptoms you have described, should you say it was unsound or not?

"Witness.-Unsound when sold, inasmuch as you would be able to trace the effect from the cause.

"Mr. James Turner stated, that crib-biting, in his opinion, was, in the greater number of instances, a habit contracted by imitation. Whether it was or was not injurious to the health of the animal, depended upon the degree in which it existed. Witness believed that a horse might he a crib-biter and yet be perfectly sound; but he believed also, that it was decided unsoundness in many cases. It showed itself more particularly by the animal distending its body with 
wind, but all crib-biters did not distend their bodies with wind in the same degree. It could not be considered as a vice, inasmuch as cribbiters were generally perfectly tractable to ride or drive, and they did no danger to their owners. "George Gosden stated, that he had been a veterinary surgeon for sixteen or seventeen years. Had known the habit of crib-biting to exist in various degrees.

"The Attorney General. Is it necessarily a vice or an unsoundness?

"Witness. Neither.

"Have you known horses to have that habit in a considerable degree, and yet to be extremely healthy for a number of years, and be capable of doing their work?-I have. I have known the best of horses to be crib-biters.

"Do you know that the horse called 'The Colonel,' had the habit of crib-biting?-I have heard he had it for a number of years.

"Sir J. Scarlett. Does your experience agree with that of Mr. Coleman, that it very rarely arises from imitation; or with Mr. Turner, that it generally does?-That it generally does.

"As in your opinion, it is neither a vice nor an 
unsoundness, allow me to ask you, whether it is an advantage? - It certainly is not an advantage.

"Is it a merit?-Yes. (Laughter.)

"The witness explained, by saying he meant to state that 'a slight' crib-biter was neither an unsound nor a vicious animal.

"What is a 'good stanch' crib-biter?-An old horse that has had it for a long while. (Great laughter.)

"Is the health of an old stanch crib-biter affected by the habit?-Not unless the stomach or bowels are affected.

"Is it a disadvantage to have a crib-biter where the habit exists in a great degree?-Sometimes it is, sometimes not.

"You would not then give a guinea less for a horse because it was a crib-biter?-Perhaps not, if it had it only slightly.

" Perhaps you have cured some crib-biters?No; I never have.

" Have you ever attempted it?-No.

"What remedy would you apply if you were to attempt to effect a cure?-Tie his head up to the manger. (Laughter.)

"Would that cure him?-It would not. 
"Lord Tenterden. Why should you do it then? -It would prevent him from biting the manger. (A laugh.)

"John Lythe, a veterinary surgeon examined by Mr. Hutchinson. Have you known horses to have the habit of crib-biting, and yet their general health not affected by it?-Many; in the army particularly.

"If they have it not in a degree to affect the health of the animal, are they, in your judgment, unsound, becanse they are crib-biters?-Certainly not.

"When they have it only in a slight degree is it a vice?-Not unless it disposes the horse to some bodily mischief.

"The witness, on cross-examination, stated that the habit arose frequently from want of food, and frequently from irritation; and he mentioned an instance of the latter.

"Is it a desirable thing for a horse to have?It is not desirable, certainly; but I never cast a horse for it.

"Lord Tenterden, after Sir James Scarlett had replied to the defendant's evidence, stated, that the question for the jury was, whether the horse was unsound, or laboured under a defect which 
could be properly called a vice. His Lordship was about to sum up the evidence, but the jury interposed, saying their minds were made up.

"Lord Tenterden. You find for the plaintiff, gentlemen?

" $A$ Juror. Yes, my Lord.

"A verdict was then entered for $£ 410 s$. $6 d$., the difference between the price which the plaintiff had paid for the horse and the net proceeds of the sale."

From this it appears, that the horse was warranted sound and free from vice : but it is not said, whether the jury regarded it as an unsoundness or a vice. My own opinion is, that crib-biting in every case, constitutes unsoundness; for though it is difficult to say whether the habit is produced by disease, or by imitation, yet it is certain that it cannot exist long, without in some degree impairing the function of the stomach: and dissection shows, that alteration of structure is a consequence of its long continuance, and that, to a greater or less degree, diminishing the efficiency of the animal. It is no argument against this to say, that crib-biters often work well : the question is, would they not work better without such a labit? It is likewise 
well known, that crib-biters are very liable to attacks of cholic, in consequence of their filling their stomach and bowels with air: and this may, often does, carry the horse off after an hour's ill ness. So that the buyer should think well, before he makes up his mind to keep a cribbiter. He often makes himself quite unfit for great exertion, by distending the stomach in such a manner as to impede his breathing.

\section{The Teeth}

In front of the lower jaw are examined to ascertain the animal's age. As few horses change hands before they are three years old, I might be content with describing the appearances which the teeth present after that period: but as it requires little room, and may possibly be of use in some cases, I shall begin with the colt's mouth soon after his birth.

The horse, like many other animals, has two sets of teeth; the first, called the temporary or milk teeth, are in general all above the gums by the time the colt is six or eight months old; and soon after he is two years, these drop out 
in pairs, to make way for the permanent, or horse teeth. They have all made their appearance by the time the horse is five years old, and he is then said to be full-mouthed, having twelve grinders, two tushes, and six nipper's in each jaw.

Each of the front teeth, when they first appear above the gums, has an oval cavity in the centre of the wearing surface, which dips into the tooth like a funnel, becoming narrower towards the bottom; and as the teeth are worn down by friction, this cavity gradually diminishes in depth and in breadth, till in time it is altogether obliterated; and as this takes place at stated periods, it affords a pretty correct criterion of the horse's age. It is improper to say that the cavity or "mark," fills up, for it is actually worn out by the action of the opposite teeth.

The following refers only to the front of the lower jaw.

About eight or ten days after birth, the colt has two nippers in the centre of the jaw.

Some time between the second and fonth month, other two make their appearance, one on each side of the first and central pair.

And betwixt the sixth and eighth, another pair is added, making six in all. 
After this period, and until the horse teeth appear, the "mark," guides us in determining the animal's age.

At twelve months, the cavity is all but obliterated from the two central nippers; and in those on each side of them, the "mark" is less extended from side to side than it was at first.

At eighteen months, the "mark" is gone from the four central teeth, and the two that first appeared are nearly triangular on their wearing surface, taking the shape of the root as they are worn down to it.

At two years, the "mark" is gone from all the six, and the two central teeth appear considerably smaller than the side ones.

At two and a half years, the two central milk teeth become loose, drop out, and the first two permanent nippers appear in their places, and are soon on a level with the remaining four milk teeth. The permanent nippers are larger and darker coloured than the temporary ones, and their external surface has a well-marked furrow, which is not observed in the colt teeth.

Soon after this period, if the colt has been well fed, and is tolerably well furnished, it heoomes an object with the breeder to pass him 
off for a four year old, as some months' keep will thereby be saved. He therefore pulls out a milk tooth on each side of the two central permanent ones, and then other two horse teeth make their appearance much sooner than they otherwise would, and the colt brings a four year old price, while in fact he is but a few months past three. This deception may sometimes be detected by examining the grinders, but in general the animal's youthful appearance is sufficient to show that he is not yet fit for work.

At three and a half years, other two permanent teeth make their appearance, one on each side of the central pair : and before the colt is four years old, they are on a level with the corner milk teeth, which are now yellow on the wearing surface, and very small at the neck, where it joins the gums.

At four and a half, the corner teeth come up, and by the time the animal is five years old, they are level with the others. Before this time, if a horse, he has likewise four tushes, and the colt is now called a horse, and the filly a mare. A few mares have tushes, but the majority have none.

At six years old, the "mark" is gone from 
the two central nippers : they being the oldest by a year, are of course soonest worn down.

At seven, the "mark" is worn out of the four central teeth, and at eight the majority of horses lose all "mark," and afterwards he is very improperly styled aged.

Many horsemen, after the "mark" is worn out of the lower jaw, have recourse to the upper one, the "mark" remaining in its teeth much longer than those of the other. But, in general, they offer but uncertain criteria of the age, for their wear is exceedingly irregular, and scarcely four horses can be got together, whose upper teeth present any thing like the same appearance at the same age. I do not therefore place any dependance on them; neither do I regard the tush as at all indicating the age: for though some rely much on its height, sharpness and the degree of its concavity, yet these are so irregular of themselves, and so much altered by the bit, that it is almost useless to look at them. Indeed, it is rather rare to find two tushes in the same jaw exactly resembling each other.

Up to eight years, there is little difficulty in determining the age by the nippers of the lower jaw, and, I believe, we must still adhere to them 
when we want to go further. Their shape, though by no means so good a criterion as their mark, is yet characteristic enough of age to enable us to come within a year or two; and no horseman need foolishly boast of being able to do more, for the thing is of such a nature as to make it morally impossible to draw an infallible conclusion upon any such grounds.

At ten years, the central nippers, instead of being nearly oval on the wearing surface, as they were at seven, have become narrower from side to side, and broader from before backwards.

The fang of the nippers tapers towards the extremity, and is narrower from side to side, and broader from before backwards, than the tooth above the gum is; and as the nipper wears down, it assumes on its surface the shape of a transverse section of the fang at different places.

At eleven years, the four central nippers are also altered in their shape, and at twelve, the corner teeth have the same shape which the two central ones have at ten, while they have now more distinctly approached to the triangular form of the fang. I need not proceed further and indeed to say the truth, if the horse be above tweive, it is not of much consequence 
whether he be two or six more, provided he is under twenty, and fresh and able-like in his appearance. If he has been well taken care of while young, he may be as good a horse at fourteen or sixteen, as, I am sorry to say, most of those now met with, are at ten, in consequence of being too soon, and far two hardly worked. The purchaser need not reject a horse because his mouth is too old to express his age; if his limbs appear clean and firm, it is a pretty certain sign that he is yet able to do much work, as far as age is concerned: for few, far too few, horses become useless from natural decay. In ninety cases out of a hundred, the animal is driven, if I may say so, to old age, and then almost every part of his frame bears testimony to the fact.

Besides the teeth, some conclusion may be drawn regarding the animal's age from his general appearance. When old or worn out, (for here they are nearly synonymous terms, ) he is listless to excess, regardless of surrounding objects, heedless of either the whip or the voice of the driver, and apparently, but only apparently, insensible to pain. The spine becomes curved downwards, while the bones composing it form a ridge 
extending from the mane to the croup: the hairs about the face and forehead become gray, the lips hang apart, the whole countenance has a peculiarly anxious-like expression: and above the eye, a deep pit appears, which along with the eyelids, contribute to form the anxious-like expression so peculiar to a worn out horse. And this leads me to remark another talent which horse-copers have got. In order to hide this cavity over the eye, they prick the skin covering or rather lining it, and blow in a little air, which for a short time fills up the pit, and subtracts not a little from the horse's aged appearance, and thereby deceives the uncautious. This operation is learnedly called "puffing the glimms." Like bishopping, however, it is beyond comparison far oftener practised about London, than in Scotland.

I ought to remark that although the teeth are continually wearing, yet as a horse gets old, they appear to grow longer, but they are not really so, it is the shrinking of the bone and gum from them, that produces the apparent elongation.

I may also here mention a fact, that horses much kept at erass, and especially in a sandy 
pasture, lose the mark much sooner than those in the stable. The reason is, that the front teeth have little or nothing to do in stable-feeding; while the horse is out, they have all the grass to cut, and that often so rough and sandy, as to wear the teeth very fast. The purchaser may bear this in mind, and make allowance for it.

Before quitting the teeth, I must take notice of a rascally trick sometimes played by some of our honest dealers. It is called "Bishopping," from Bishop being the name of the ingenious inventor. It consists in making an artificial mark, after the natural one is worn out; and is done by scooping a piece out of the surface of the tooth with an instrument made for the purpose, and then blackening the cavity with a hot iron, or instead, a clumsy job is sometimes made of it by using lunar caustic. Commonly only the corner teeth of an eight years' old mouth are thus operated upon; and then the horse is "warranted sound, and only seven years old." Sometimes the next corner teeth are likewise bored and burned, to make a six year old; and indeed, I have seen all six equally well bishopped; when the shape and length of the teeth 
plainly told, that the horse must have been at least twelve years of age. But so wise are the "knowing ones," that as they only look at the mark themselves, they never dream of another comparing that with the shape and length of the tooth, and hence to more acute observers they unwittingly display their roguery in all its nakedness.

The imposition may be discovered by the irregular roughness on the sides of the cavity of the teeth-the unnatural darkness of the mark -the absence of a white ring of enamel that always surrounds the natural cavity: and that, compared with the length of the body, and the shape of the surface, will render imposition exceedingly difficult. The bishopped horse is likewise loath to allow you to examine his mouth, being fearful of a repetition of the pain which he suffered while undergoing this disgraceful operation.

A bishopped horse is not of necessity an unsomnd one; but he is returnable to the seller, who makes himself liable to an action for having used fradulent means to get a purchaser. See note, p. 41. 
THE VEINS OF THF NECK.

The Veins of the Neck.

One of them is sometimes obliterated in consequence of becoming inflamed after the operation of bleeding. Such a deficiency in structure may be discovered, by placing the finger on the lower part of the neck, and compressing the vein sufficiently to stop the passage of the blood. If the vein is entire, it will be seen to fill and swell upwards from the point of pressure.

The loss of a vein I consider an unsoundness, because, even for many months after it has been shut up, the blood cannot pass so readily from the head; and if the lorse ever needs to be turned out to grass, his head will probably swell from the accumulation of blood, and he will be predisposed to bad eyes and staggers. The purchaser need not, however, reject a liorse because he has lost a vein; for, in course of time, other veins of the neck increase in size, and among them perform the work of the large one that was lost : and then the only objection to it is, that he must not again be bled in the neck, lest 
possibly the other vein also inflame, and become impervious.

\section{The Foreleg and Shoulder.}

Grooms and blacksmiths make the shoulder the seat of every lameness in the foreleg, when their acuteness is not sufficient to enable them to discover it any where else: but the fact is the shoulder is very rarely diseased, and hence, in an examination for unsoundnesses, it is a part not much looked to. Tumours on the seat of the collar, however, are not unfrequently met with; and when large, they must either be cut out, or a collar must be used of such a construction as to avoid pressing upon them. Except under such circumstances, a tumour of this kind does not make a horse unsound; if he is bought entirely for the saddle, then it is only an eyesore; but if he is bought to go in harness, and the tumour be of such a size or nature as in the least to unfit him for wearing the collar, then the horse is unsound. 
The Point of the Elbow is sometimes the seat of a large and ugly tumour, produced by the heel of the shoe bruising it, when the horse is lying with the leg bent under him.

I never saw a case where it interfered with the horse's action; and unless it does so, it is merely a blemish, not an unsoundness.

The Front of the Knee is invariably scrutinized with the utmost severity by every purchaser at all acquainted with horses. If the hair be rubbed off, it is a symptom, that the horse has at some time fallen, and injured himself: and it is a popular, though erroneous opinion, that if he has once come down, he will be ever after very apt to do so again. This error has had its origin in, and is perpetuated by, the fact, that some horses come down very frequently. But they do so, because they are not well formed for the saddle; having either a low forehand, or a heavy head, or an upright shoulder, or what is a natural consequence of these faults, they lean so much over their forelegs, as to be very easily thrown on their knees. In a horse that is known to fall often, some, or all of these defects will be found in his conformation, but there is nothing in the nature of the injury of the skin, that can at all make him 
liable to fall. It is true, however, that now anu then the injury has been such as to affect the joints, and the bones of the knee, in such a way as partially to stiffen it; but this, compared with the simple injury of the skin, is of rare occurrence. It is an easy matter to ascertain whether the knee joint be perfect or not; the purchaser has only to lift the foot, and bend it backwards, till the heel of the shoe touches the point of the elbow. If it cannot be bent so far, the horse is unsound, unfit for quick work, and liable to fall at any work on a rough road, or in deep ground. But, of course, the degree of this unfitness and liability will depend upon the degree in which the knee is stiffened: but the least degree constitutes unsoundness; and I may observe, that though there is a probability of the evil increasing, yet there is none of its decreasing: and knowing this, the purchaser will act accordingly.

When the hair is awanting in the front of the knee, the horse is said to have had broken knees, which shows how the evil is estimated. It is a mere blemish, no unsoundness; unless, as I have already observed, the structure of the joint is affected. 
Immediately below the knee joint, on the inside, the skin will, in some cases, be found abraded, and the bone enlarged. This is produced by the opposite foot striking it, when the highactioned horse is trotting fast. It is denominated Speedy cut, and is only objectionable, as indicating bad action, but is no unsoundness.

Between the knee and the fetlock joint, on the inside, and some way between the knee and the middle of the shank, a little bony tumour is found, called Splent. Few horses, after a year's work, are free from it. At its commencement it is attended with considerable lameness; yet, after a time, the lameness goes off, and we can perceive no difference between the action or ability of a horse with, and one without splent ; unless, indeed, it become, through neglect or improper treatment, so large as to interfere with the motion of the back tendons. When it does so, the horse is unsound: but not otherwise.

Strain of the back tendons is a very common occurrence in the horse, and more especially so in heavy draught horses, and those with long and slanting pasterns. When it has been severe it is a long time before the attending enlargement is entirely removed; and while any remains, the leg is weak and easily re-injured 
I would here remark, that in every actual or suspected case of enlargement, of any part of the limbs, the examiner may make up his mind with precision as to its existence or non-existence, by comparing the suspected part with the same part in the opposite leg: for it rarely happens that both have the same disease, but when they have, the degree of enlargement differs, which is enough to show, that there is deviation from health. So, the enlargement left by an old strain, may be so slight, as not to be recognised by the eye, yet detected at once, by carefully and slowly drawing the thumb and first two fingers down the whole length of the back tendons of each leg. Some staring of the hair may hint that the leg has been blistered, and may strengthen the opinion you have formed, after comparing the fineness of the two legs by your hand.

The remnants of a strain in the back tendons make a horse unsound, inasmuch as, though he may, at the time of sale, appear perfectly free from lameness, yet these tendons have so much work to do, that they cannot afford to lose any of their original strength.

The Fetlock Joints are frequently the seat of bony and tendinous enlargement : they should, therefore, be well examined by both the eye and 
the hand. When enlargement does exist, it in almost every case constitutes unsoundness. The inside of the fetlock joint should be examined, to see if the horse is a cutter, that is, one who strikes the fetlock with the opposite foot, and cuts the skin. Cutting is a natural defect in the animal's conformation or action, and cannot, however objectionable, be called unsoundness.

Windgalls are little puffy tumours situated directly above, and almost on, the fetlock joint. They are little bags containing a fluid for lubricating and preventing friction, between a tendon and two little bones, which it here passes over: and it is an increase of this fluid, commonly called joint oil, which distends the containing bag, and constitutes windgalls. Few horses are without them, and they do not constitute unsoundness; but they show that the animal has done a good deal of work.

The Fetlock is sometimes subjected to an operation, which may, and has before now, aided the roguish seller, and cheated the purchaser. The operation is called unnerving, and is performied, not by a dealer, but by a veterinarian, for the purpose of destroying sensation in the foot of an incurably lame horse. It consists in making an 
incision throngh the skin, either directly above, or below the fetlock joint; and then dividing, or even entirely removing, a small portion or the nerves that supply the foot with sensibility. After this, the groggy horse appears perfectly sound: but it must be remembered, that the disease is not cured, though the pain and lameness are removed. In many cases the disease goes gradually on, till the horse breaks down, throws off the hoof, or, in some other way, becomes quite useless. This is quite a common affair in England: but in Scotland, the operation is rarely practised. Where it is performed merely that the horse may be'got rid of, the usual result is that which I have just mentioned: but there are other cases, where, when properly performed, it makes a perfect cripple serviceable for many years, and is a useful operation, notwithstanding what has been said against it, by those who neither know how nor when to perform it. But the purchaser, who can neither know why nor how it has been performed, should never buy an unnerved horse.

Sometimes one, and sometimes both legs are operated upon: and as the incisions never heal so weli as to leave no trace of their having been 
made, the scar in the skin should be looked for on each side of the fetlock; it is generally under, though sometimes above, that joint.

The mere division of the nerve would only make a horse unsound, until its ends unite, as in time they will; but then, the operation is almost always performed for a disease that always remains and makes the horse unsound for life.

The Pastern, or space between the fetlock joint and the top of the hoof is the seat of a bony tumour, called Ringbone. It may be discovered by its prominence, and, when it exists, it constitutes unsoundness. But many a horse has worked well for many years with a small ringbone.

\section{The Foot.}

Side bones. Immediately above the hoof, at the heels, and stretching somewhat forward on each side, and having the hollow of the pastern between them, are two elastic bodies, called by veterinary surgeons the lateral cartilages. When in health, they bend inwards and a little out. 
wards, to the pressure of the finger and thumb; but they are liable to a disease, which renders them partially or wholly inelastic, and frequently makes them so prominent as to invite attention. They are converted into bone, and stable-men say the horse has side bones. It is a disease most commonly met with in heavy draught horses, and is one which constitutes unsoundness, inasmuch as it produces more or less tenderness in all its stages: and if the horse has to be driven about a town, it will, in time, proceed to such an extent as to make him a perfect cripple; and besides that, it makes the bone of the foot liable to fracture. To a farmer, l:ow. ever, a horse having side bones may be useful for many years, at any work where the ground is soft, and the pace slow.

Sandcrack is a fracture of the hoof, or a separation of the fibres composing it. The fissure is commonly found in the inside quarter of the hoof, and varies in length from half an inch to the whole depth of the crust. It sometimes occurs in the market-place, where the horse is driven violently about on the stones; and the buyer should therefore look for it, because it may be so small as otherwise to 
escape notice: and if he has once got the horse home with a sandcrack, there is little or no probability of getting him returned : for, unless something about it shows that it has been treated, no veterinary surgeon can swear that it existed prior to sale. It is an unsoundness, however, if it did.

Contraction. The foot may be said to be contracted, when it is narrower from side to side, than it is long from the point of the toe to the heel of the frog. Most people regard a contracted foot as being a great detriment to the horse: but it frequently happens that the very people who do so, have a horse whose foot is very narrow, without their being aware of it ; which, along with many other circumstances, shows, that it is not so serious an evil as is commonly imagined. Indeed, there are very few well-bred horses above the age of seven, that have not more or less contraction in their hoofs, and yet show no symptoms of being in the least incapacitated by it. A fact we need not wonder at, when it is known, that where the contraction comes on very slowly, the parts within accommodate themselves to the diminished size of the hoof, and hence we have a small foot, which of 
itself would scarcely ever be deemed an objection, if it were not known that lameness is so common an attendant upon it. For my own part, I would not reject a horse, merely because its feet were contracted, provided both were equally so, and free from heat and tenderness; and the horse's action such as to assure me, that no disease existed in the foot besides the contraction: and therefore though I never pass a horse without pointing it out, yet I endeavour, at the same time, to explain its harmlessness. But, where one foot is smaller than the other, it alters the case: I am then certain, that there either is, or has been, some long-continued cause of lameness, existing either in the leg or foot: and the discovery of that in many cases, sufficiently warrants me in saying that the horse is unsound, without taking any notice of the smallness of the foot, which may here be only a natural consequence of the animal's setting less weight on it than the other. Contraction alone is therefore not unsoundness.

Thrush. Every man at all acquainted with horses knows a thrush when he sees it; and I need not, therefore, give directions for discovering it. It is a disease very frequently met 
with, and one that, in some cases, exists in so trifling a degree, as almost to escape the observation of a superficial examiner: while, in other cases, its magnitude is such as to give the foot the appearance of being "rotten for good and all." Sometimes it consists in a very trifling discharge of matter from the cleft of the frog: at other times, the frog is small, ragged, soft, and useless. It is the various degrees in which it exists, that have produced the great diversity of opinion that prevails regarding how far it constitutes unsoundness : one party contending that a thrush, in every case, makes a horse unsound; and another, that in some cases it does not. The question has been tried more than once in a court of justice : but the lawyers aver, that the evidence was so contradictory, that no general rule could be laid down. It is a disease, as I have already observed, so common, and so seldom attended by any apparent bad consequences, that few people object to it; and I am inclined to believe, that the horse is often returned to the seller for having a thrush, when the actual objection is something having more alliance to some fault for which he cannot be returned. The purchaser perhaps rues his 
bargain : the horse is too dear, or is found to have some defect in his action or conformation, and the thrush is made a handle of to get rid of the horse altogether.

Not long ago, I was one of those who do not consider every case of thrush an unsoundness : but I find so much difficulty in fixing upon the proper degree in which it must exist to do so, that I now consider thrush as one of those diseases, that, strictly speaking, make a horse less useful than he would be without it. If it be neglected, it will increase: the frog will become tender, and the horse shows it, when among small stones, or on a newly metalled road. The foot contracts: and if, at this period, any attempt is made to dry the discharge, the horse becomes lame, unless it is very gradually accomplished: and then too, not an unfrequent result of long continued thrush is a much more fornidable disease, called Canker, which is tedious and difficult to cure; so that upon the whole, a thrush may not be so trifling a matter as is generally considered. It is an unsoundness, according to our definition of that word. I am aware, that in its commencement, it is very readily cured, and the seller never fails to 
tell the purchaser so: but why does he not cure it himself? Objections and returns would then be done away with, at least as far as thrush is concerned.

The purchaser will infer from what I have just said, that I do not by any means advise him to reject a horse with slight thrushes, or even one with them in a somewhat advanced stage, provided the horse pleases him otherwise, and he gets him at such a rate, as to afford the expense necessary in curing what may probably become a more serious evil.

Corns cannot be discovered without removing the shoe; so that, when you suspect their existence, you had better accompany the horse to the forge, the first time he goes there to be shod. They are found at the extremity of the sole, between the crust of the hoof and the bars; and they are known by the horn at that part being discoloured with blood. If the blacksmith can remove this reddish horn with his knife without bleeding the foot, there is nothing to fear : there has been a corn, but there is not now.

If corns exist in such a degree, as to render more than ordinary care necessary in shoeing, the horse is unsound, but not otherwise : for a 
corn may be produced by an ill put on shoe, the removal and properly replacing of which will remove the corn.

Flat soles are not always the result of disease. When they are so, the crust (or all that part of the hoof exposed to view, when the foot stands on the ground) runs very obliquely from the termination of the skin to the ground; and transversely, it is marked by alternate ridges and furrows. Such feet are very objectionable in any horse, but particularly so in a heavy one, who has to work in or about a town : for if the feet ever again become inflamed, there is every probability of the sole bulging out, and becoming so convex as to render the animal all but useless. Sometimes the foot is naturally flat, and then it does not, as in the other case, constitute unsoundness: the horse having the diseased flat foot may be more particularly distinguished from the other by his gait, which I have to speak of by and by, under founder.

The Shoe should be looked at, in order to assist in determining whether or not the horse cuts himself. If a bad cutter, he will either have the inside branch of the shoe considerably thicker than the outer one, or he will have a 
ligh ealkin on it, and the nails will be driven principally in the outside, and round the toe : and the hoof will hang a little over the outer edge of the inside of the shoe. I havealready mentioned, that the fetlock should be examined for the same reason that the shoe should: both should be attended to.

\section{The Chest and Quarters.}

Each side of the cliest, immediately behind the point of the elbow, should be examined, to discover the marks left by blisters, setons, and rowels. If any are found, it will be pretty certain evidence, that the horse has had inflammation in the lungs; and as it is possible the disease may not have left these organs uninjured, the wind should be well tried by a smart gallop before purchase.

The Skin between the Forelegs should be examined for the same marks, and for the same reason that the side should. The hair staring, being thin, and running irregularly in different directions, are signs that a blister has been there 
recently, while little, bald, and somewhat knotty spots, are as certain signs of the recent use of setons or rowels. It is impossible to say from these appearances, that the horse is unsound: they only show, that he has had, or been treated for, a disease which often makes him so.

The Haunch bones should be compared with each other, to see that they are equally promin. ent : for sometimes a piece is broken off one by accident. The examiner will see this best, by standing a little way directly behind the horse. If but a small piece has been chipped off, and the horse does not seem to suffer from it, he cannot be said to be unsound: and he is only, therefore, objected to for the deformity, which, by the way, is sometimes so trifling, as to exist without the owner of the horse being at all aware of it. There is a mare working in a stage-coach in the neighbourhood of Glasgow just now, which has had so large a piece broken off the haunch bone, as to form a deficiency in the prominence of the belly on that side: and yet she does her work as well as her companion. But I should think she would be unable to take any thing like a considerable leap. 
The Stifle is rarely diseased, but any enlargement of so important a joint must be considered as an unsoundness.

The Groin is now and then the seat of a soft compressible tumour, varying from the size of an egg to that of a man's head. It is formed by the escape of a portion of bowel from the cavity of the belly, and is the same with what is denominated rupture in the human being. It is oftenest met with in the stallion, and then it occupies the same bag with the testicle. But though rupture, or hernia, as it is called in medical language, is oftener met with in stallions than geldings, yet it so rarely occurs in either, that few look for it. It can do no harm however, to take a glance at the groin, and see that all be right.

Hernia is decidedly an unsoundness.

I may here observe, that in purchasing a stallion, the testicles ought to be examined: but the assistance of some one acquainted with their healthy structure will here be necessary.

The Hock.

It has been often remarked, that the fcot 
before, and the hock behind are subject to more disease than any other part of the lorse. It is an observation founded on experience, and should not be forgotten by the purchaser, when examining those parts.

Capped Hock is a swelling on the point of the hock, produced generally by the horse kicking in the stable or in harness. It never produces lameness after the inflammation which accompanies its commencement is subdued, and is therefore not an unsoundness; but it is an ugly blemish, and one that, in many cases, belongs to a vicious horse.

There is another kind of swelling on the point of the hock, differing from the former by being attended with lameness, and especially so after a hard day's work; consequently it is an unsoundness; but the Veterinary Surgeon is the only person fit to distinguish between this and the mere blemish : though as both hocks are rarely affected in this case, and are generally so in the other, the purchaser runs less risk in getting a loorse with two, than only one capped hock.

Curb is a longitudinal swelling, found at the back of the hind leg, and three or fonr inches directly below the point of the lock. It is best 
seen, when the examiner stands a yard or two from the side of the horse. A small curb does not make a horse unsound, neither does a large one, unless the horse become lane from it when put to work, which rarely (perhaps never, but under over-exertion) happens, after the pain and inflammation are removed which attended it at its commencement.

Thorough $\mathrm{Pin}$ is a tumour of the same nature as windgalls, and is of no more consequence. It is situated on each side of the hock joint, about an inch above and behind the centre of motion.

Bone Spavin is a diseased state of the small joints and bones which enter into the formation of the hock. It is a disease of very frequent occurrence, and, with the exception of curb, almost the only one belonging to the hock, which produces lameness. To discover its existence is not always an easy matter: on the contrary, the horse may be dead lame from spavin, and yet the most skilful veterinarian is unable to say positively, whether the lameness proceeds from that disease or some other. Many people suppose, that spavin does not exist, till there is a bony 
swelling perceptible to the eye : but this is quite erroneous, for as bone grows very slowly, and as, in this case, inflammation and pain are at first necessarily combined with, and must even precede, the formation of the bony tumour, it follows, that we must have lameness, long before we are informed of the cause by external enlargement. The horse with spavin, however, is, in almost every case, lame from the commencement of the disease, till the hock is enlarged: and then the lameness subsides into stiffness: and then, but not before, the horse is offered for sale: so that the purchaser will not find it a very difficult matter to guard agaiust spavin. It makes its appearance on the inside of the leg, and most commonly at that part where the hock joint terminates and the leg begins. In some cases, both hocks are affected: but, at a rough guess, I would say, both are not equally so in more than one case out of a. hundred; and it is the inequality of the erlargement that will enable the examiner to decide whether the hock be naturally large, or increased in size by disease. Let the eye and the hand be both used in comparing the hocks with each other; and look at 
the toe of the shoe, and the hoof, to see if they are worn away by the horse dragging his foot along the ground.

Bone spavin, in whatever degree it may exist, is decidedly an unsoundness. A spavined horse may appear to do his work well for a long period; but, if closely observed, he will be found to be always a little stiff, and that stiffness will never entirely disappear; though it nay be predicted with safety, that it will sooner or later end in downright lameness, unless the horse is kept at work which never requires the full exertion of his powers; for the disease is of such a nature as in most cases to remain stationary, if the cause that first produced it is not re-applied -over-exertion, and over-weight.

Bog Spavin is a swelling in the front, and rather to the inside of the hock, on the centre of the joint. It is of the same nature as windgalls and thorough pin, and only to be regarded in the same light as these two indications of overexertion.

Over the middle of the tumour, constituting bog spavin, a vein runs, which, by the distention of the bag beneath, is always pushed a little out of its place, and then appearing more prominent, 
the groom thinks it is a disease, and calls it blood spavin. . Dissection, however, and measurement of the vein, show no trace of disease, neither, when filled with wax in the dead subject, does it appear at all larger, than where neither bog nor blood spavin had existed.

Below the hock joint, the leg should be examined for strains, the fetlock for enlargement, windgalls, and cutting, the pastern for ringbone, the foot for side bones and thrushes. The other diseases mentioned as belonging to the foreleg and foot, are rarely, and some of them never, seen in the hind foot.

Suppose the purchaser to have proceeded thus far in his examination, he will next have the horse trotted upon the stones, to see that he is not lame, either before or behind. I need not attempt to give directions for discovering lameness, for no man should, unaided, buy a horse, if his knowledge of that animal be too scanty to enable him to discover it himself. I may observe, however, that, as lameness in the forefeet or legs is shown by the motion of the animal's head, care must be taken that the seller do not hide this symptom by holding the horse's head so firmly, as to prevent its up and 
down motion. Let the horse have the full length of the rein to himseit, for his head is fixed, when the groom takes what he calls a short hold. The horse's action should at this time be attended to, for if he be tender on both forefeet, it is much less likely to be observed, than if only one were affected. A groggy horse has passed often enough for "warranted sound," when his action would, a priori, have informed an experienced horseman of his unsound condition. The groggy horse shuffles his feet before him as if the whole leg were stiff; he goes very near the ground, and treads so lightly, that he reminds one of a " cat on a hot girdle." A horse with such action, is called by stablemen a "daisy cutter."

Lameness, however trifling, or from whatever cause, is an unsoundness : and, I suppose, no one (excepting of course our small, yet gentlemanly dealer,) would buy a lame horse, without knowing the cause and probable termination of the lameness.

Founder is a name given to an inflammation of the foot, which frequently leaves bad effects behind it, without their immediately showing them. selves in an altered state of the hoof. In many 
cases, the horse's action shows that all is not right; and in time it is demonstrated by the descent of the sole. When an attack of founder has permanently injured, yet not totally ruined, the foot, it will be discovered by the peculiar way the foot is placed on the ground, when the horse is in motion. Instead of coming down almost flat from the toe to the heel, it will be observed, that the heel comes first in contact with the ground: and if the horse has raised heels on his shoes, this peculiar tread will be rendered more conspicuous. It is best seen when the horse is trotting in a straight line towards the examiner. Besides setting the heel of the foot down before the toe, the foundered horse projects his foot forward in a loose, jerking manner, which, of itself, is a characteristic symptom of this disease. The state of the hoof is another: mentioned at p. 92.

This disease, for disease it is, though only the remmant of a more violent one, is without doubt an unsoundness: it can never be entirely cured, and will, after the horse has liad a hard day's work, so much increase, as to make him actuaily lane: and if he be, as he generally is, 
a heavy horse, and has to do quick work about a town, he will sooner or later become next to useless by the sole becoming convex : and from first to last, he requires particular care in shoeing.

Stringhalt, or Click spavin, as it is sometimes termed in Scotland, consists in lifting one or both of the hind legs to an unnatural height, and in a convulsive manner. It is supposed to be a disease of the nerves, but its nature and cause are not precisely known; for dissection throws no light upon either. We might expect, that the awkward way in which the horse uses his legs, would very soon fatigue him; hut it does not appear so, and therefore it is not reckoned an unsoundness. It, however, gives the horse a very ungraceful appearance.

Disease of the Loins, is indicated by the unsteady motion of the hind legs; and when the horse is backed, or turned smartly round, he threatens to fall. In every case, it constitutes unsoundness : and the cases of recovery are so few, and the horse is so useless, that he had better be altogether rejected. 


\section{The Lungs.}

Ancther important point in the examination of every horse, is that of the air passages. They ar: very subject to disease, and as much of tho, horse's utility depends upon his "wind," it should in every case be put to the test.

Broken wind. The most infallible symptom of this disease, is the peculiar heaving of the flank. In health it alternately heaves, and falls, and takes as much time to do the latter as the former. But in a broken-winded horse, the flank rises about half-way, pauses there a moment, then goes on, and drops in an instant, as if suddenly, and forcibly thrust down. In this way the flank falls in less than half the time it occupies in rising; and this is the chief symptom of broken wind. But there is another, when the horse is made to cough, by compressing the head of the windpipe, he utters a short, low, grunting sound, not unlike the cough of an old asthmatic. It is not the clear sonorous cough of a horse in health. Dealers give, or aim as if they were going to give, the horse a blow on the side, wheil they want to try his wind; and if 
this elicits a grunt from the horse, they say he has diseased lungs; and so in general he has; but not always, neither does he always make this noise when he has. It is therefore a bad test.

I need hardly say that a broken-winded lorse is an unsound one. Every body knows it. The disease does not however render the horse useless; on the contrary, we frequently, meet with a broken-winded horse, following the hounds as well, or almost as well as the best in the field. But to do so he must be well taken care of, and then in spite of all care, he will sometimes be good for nothing. The least change of diet, or weather, seems to have a singular effect upon him.

I have heard of drugs being given to conceal the symptoms of broken wind, and they certainly do so to a certain extent, and for a short time; but I know of no method by which the imposition may be discovered, except his peculiar cough, which cannot be altered by any means.

Roaring, whistling, wheezing, piping, puffing, and thick wind, are names given by stablemen to different stages, or modifications of one or two diseases of the air passages, which, by partially 
obstructing them, produces a noise, varying in eharacter according to the seat, and degree of the disease.

The obstruction is rarely so great as to prodice any noise in the breathing while the animal is at perfect rest. He should therefore be mounted, and get a gallop, either up hill, or in deep ground, or sufficiently far on any ground, to increase the breathing; and if the examiner does not ride, himself, he should stand close to the horse as he comes in, that the unnatural noise, if there be any, may be the more readily heard. When the dealer wants to conceal the noise of roaring, \&c., he takes the horse out a considerable distance before putting him to the gallop; and in returning be slackens the pace, so that the breathing may become tranquil before the horse reaches the examiner. This is called the "long irot."

Roaring of all kinds constitutes unsoundness.

Immediately after the horse has been gallopped, notice should be taken whether the acceleration in the breatling be greater than it usually is by the same exertion in a healthy horse: for, if the lungs are diseased, the breathing will be more or less lahorious. Some allowance, 
however, must be made for the condition the horse is in. If he is in the hands of a dealer it is probable that for weeks before he has had no work beyond an hour's daily walking exercise; and then, he has been fattened like a cow for the butcher. So that, between indolence, and abundance of food, the horse has been brought to such a state, as to be much distressed, by what at another time would not in the least incommode him. The dealer has again and again suffered, and suffered most unjustly, for selling a horse in this state; and I heartily wish some abler hand than mine would take up the cudgels in his behalf. It is his interest to make his goods look as well as they will; and in order to do so he allows the horse plenty of soft food, and gives him little or no work : then there is accummulation of fat-a sleek glossy coat; and the animal appears in high condition, and sufficiently vigorous for any work; but he is, notwithstanding, a thing of mere show; he has plenty of fire but no vigour. The purchaser, however, is not aware of this ; and, proud of his splendid new horse, he thinks nothing of knocking him about at the rate of twelve 
or fourteen miles an hour, or perhaps he at once goes "a-hunting." Now what is too frequently the result of this absurd treatment? Why, what can be expected, but that the horse should sometimes drop under his thoughtless rider? or what needs he wonder, if on getting home he finds his horse ill-bad with inflamed Jungs-and in a day or two, dead? Then comes the injustice of the thing. The purchaser takes it into his head, or perhaps his groom or blacksmith puts it in for him, that the horse must have been unsound when sold. A lawsuit accordingly commences-some pretending old fool of a farrier, who could not for his life tell whether a certain part were sound or diseased, swears that he opened the horse and found him " rotten -rotten as a pear, and long unsound." It is not inquired whether or not this witness is competent to give evidence in such a case; but the court, taking that for granted, gives a verdict in favour of the buyer. And thus the seller suffers in pocket and in reputation, because one man did not know how to take care of a horse, and another did not know that a disease may be set up and end in death, in six and thirty 
hours. It is very clear that justice can never be administered while quacks are allowed to give eridence, (at least if their evidence is allowed to have any weight,) on a thing they know no more about than the thing does about them.

And another thing, the deaier always goes into court like a dog with a bad name. It is supposed that he must have known of the unsoundness, and consequently when the cause is tried before a jury, their minds, in spite of themselves, are biassed in favour of the simple buyer; and that, coupled with their ignorance of horse affairs, and the perplexity introduced by the contradictory statements of ignorant and incompetent witnesses, make a lawsuit in this particular case, at best a mere lottery : a lottery too where the parties have very unequal chances. These remarks are not out of place. They are intended as advice to the purchaser. Let him recollect that his new horse is not fit for any thing like hard work, until he has been prepared for it by daily and gradually increasing exertion. And where a horse does die shortly after sale, get a Veterinary Surgeon to examine the body; he is the only competent person to decide 
whether the cause of death existed prior to, or was produced after, sale. And if he is doubtful, get another, "two heads are better than one :" and in such a case, if an amicable arrangement can be made with the seller, it is better than rushing into a court of justice, where no one can tell who is to lose or who to win. Those who want an illustration of this, will find one in this month's (August, 1833) "Veterinarian," where it is stated that a horse was bought, and soon after died, nobody knew what he died of, and yet the purchaser pursued the seller, and recovered the full price of the horse, with costs. So much for luw. 


\section{N D E X.}

PAGE

Action, peculiarity of the, in horses that have had an attack of founder,

Action, peculiarity of the, in groggy horses, . . 101

Age of the horse, how ascertained by the teeth, - 67

Age of the horse, how ascertained by his general appear-

ance, . . . . . . . . 73

Back, the, weak when too long, . . . . 10

Back tendons, the, should not be tied in under the knee, 18

Back tendons, disease of the, how discovered, . . 81

Bishopping, a fraud upon the purchaser, - . 79

Blindness from palsy of the optic nerve, . . . 50

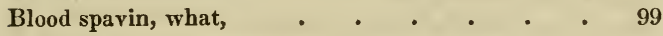

Bog spavin, nature of, not an unsoundness, $\quad$ • $\quad$ - $\quad 99$

Bone spavin, definition of, • • • • • 97

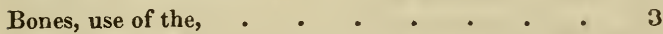

Broken knees do not make the horse liable to fall, . $\quad 79$

Broken wind, symptoms of, - • • • . 104

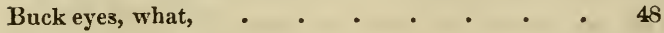

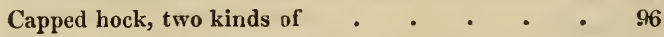

Caswell, $v$. Coare, case of, $\quad$ • $\quad . \quad$. $\quad$. $\quad$. 34

Cartilages of the foot sometimes converted into bone, 85

Cataract, how discovered, $\quad . \quad+\quad . \quad$. 48

Chronic cough generally considered an unsoundness, $\quad 54$ 
Crib-biting, trial concerning, - . - : $\quad 56$ Croup, drooping of the, characteristic of the Irish horse, 10 Cold, common, symptoms of, . . . . . 53 Contraction of the foot, not a disease of itself, . $\quad$. 87

Corns, an unsoundness when such as to require more than ordinary care in shoeing, . . . . 91

Cough, chronic, generally regarded as an unsourdness, 54 Cow hocks, what, . . . . . . . 15 Curtis, v. Hannay, case of, . • • • • 36 Cutting, not a disease, arises from defective action, 8s, 92 Delivery, laws relating to, . • • . . 23

Earnest money must be given to bind the bargain, . 24 Elbow, the point of the, occasionally the seat of a tumour, 79 Eye, examination of the, . . . . . 48 Fielder, v. Starkin, case of, . . . . . 35

Fetlock joint, liable to enlargement, - • • 82

Flat soles, not always a consequence of disease, . 92 Fraud, laws relating to, . . . . . . jy Foot, examination of the, for diseases, . . . 85 Foot, natural shape of the, . . . . . 78 Fore legs, diseases of the, - . . . 7 ) Fore legs, position of the, . . . . . ] Founder, often leaves the foot in a diseased condition, 101 Glanders, symptoms of, . . . . . . 51 Glands between the bones of lower jaw enlarged in glanders,

Grogginess, symptoms of, Hind leg, diseases of,

Hip down, fracture of the haunch, . . . 94

Hips, ragged, a defect in the form of the loins, 11 
PAGE

Hock, examination of the, for disease, $\quad$ - $\quad$ - $\quad$ - $\quad 95$

Knees, broken, not an unsoundness, $\quad$ - $\quad$. $\quad$ - 79

Knees, defects in conformation of the, - . . 13

Knees, sometimes partially stiffened, • . . 30

Lameness, in every case constituting unsoundness, . 101

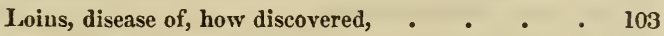

lungs, how examined, . $\quad$ : $\quad$. $\quad . \quad$. $\quad$. 104

Mange, an unsoundness, $\quad$ • • . . 20

Mark of the teeth, use of, in ascertaining the horse's age, 67

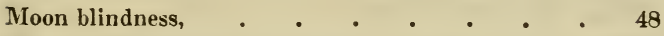

Muscles, the, the active organs of motion, - . 2

Narrow chest, a, disadvantageous, $\quad$. $\quad$ • $\quad$ • 9

Neck, the, should be light in all saddle horses, $\quad 7$

Nerves, division of the, at fetlock joint, . . . 83

Nostrils, discharge from, . $\quad$ • $\quad$. $\quad 51$

Nostrils, a plug sometimes purposely placed in them, $\quad 52$

Nostrils, should be large in all horses, $\quad$. $\quad$ 7

Nostrils, tumours occasionally found in them, . . 52

Pasterns, length of, varying in different breeds, 13

Puffing the glims, a trick of the dealer, . . . 74

Quarters, the, should be well furnished with muscle, 11

Ragged hips, a defect in the loins, • • • • 11

Ringbone, an unsoundness, . $\quad . \quad$. $\quad . \quad 85$

Roach backed, what, $\quad . \quad$. $\quad . \quad$. 10

Roaring, method of discovering, • • • • 105

Rupture, occasionally met with in horses, . . 95

Saddle back, disadvantages of, . . . . 10

Sale, laws regarding, $\quad$ • $\quad$ • $\quad$ • $\quad$ • $\quad$ • $\quad 22$

Shillite, $v$. Claridge, case of, $\quad$ • $\quad$ • $\quad$ • $\quad$ • $\quad . \quad 33$

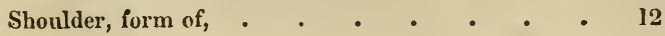


Shoulder, tumours on, - . . . . 78

Side bones, what, ..$\quad$. . . 85

Soundness, definition of, . . . . . . 17

Spavin, blood, not a disease, • . . . $\quad$ - 99

Spavin, bog, not an unsoundness, - . $\quad$ - $\quad$ - 99

Spavin, bone, how discovered, . • . . $\quad 97$

Speedy cut, what, . . . . . . 87

Spine, sunk in saddle-backed horses, . . 10

Spine, sunk in old horses, . . . . . 73

Splint, nut an unsoundness, . . . . . 81

Strain of back tendons, remains of, an unsoundness, 81

Stringhalt, not an unsoundness, . . . . 103

Teeth, the, as indicating the horse's age, . . . 67

Teeth, state of the, in crib-biters, . . . . 55

Tendons, back, how they should be examined, . . 81

Thick wind, symptoms of, . . . . . 105

Thorough pin, not an unsoundness, . . . . 97

Thrush, not to be disregarded, . . . 88

Unsoundness, definition of, - . . . $\quad 17$

Vice, definition of, . . . . . . . 42

Warranty, doctrine of, - . . . . . 26

Warranty, express, - • . . . 27

Warranty, form of, - . . . . . . 41

Warranty, implied, - . - . . . 27

Warranty, qualified, . . . . . . 42

Windgalls, nature of $f_{!} \quad$ o . . . 83

Wither's, high, important for satety, . . . 8

THE END.

GLASGOW : 


\section{POPULAR WORKS}

\section{PUBLISHED BY .}

W. R. M'PHUN, 86, TRONGATE, GLASG OW ;

SIMPKIN AND MARSHALL, LONDON;

SOLD BY ALL BOOKSELLERS.

\section{I.}

Dedicated to the Hon. James Ewing, Esq., M.P.

MI'Phun's Guide through Glasgow,

Neatly bound in pocket Size, 2s. 6d.

\section{Pocket MLap of Glasgow,}

In a. Case, 1s., in Sheet, $6 \mathrm{~d}$.

"These issue from a press in which we are more immediately interested than those of Mr. Knight and Mr. Valpy. They are published in Glasgow by the house of M'Phuna name which was associated with the diffusion of much cheap and useful knowledge throughout Scotland, long before the Society whose labours we have noticed above did exist. So wonderful a city in its progress and magnitude deserved a well-informed and trust-worthy guide; and such a guide Mr. M'Phun has furnished. It is enriched with a very neatly engraved plan of the city, a view of the city, and prospective elevations of its principal buildings."-Dumfries Times.

"This is an exceedingly useful and respectable little Work. * Numerous as have been the publications of Mr. MrPhun, this is undoubtedly one of the best of them." Dumfries Courier.

"This is a neat and well-executed little volume. From the distinct and graphic manner in which M'Phun's Guide is written, we can confidently recommend it to every one who desires an acquaintance with the lions and localities of Glasgow."-Edinburgh Evening Post and Scottish Literary Gazette.

"M'Phun's Guide through Glasgow is a beautiful little volume."-Glasgow Chronicle. 
II.

\section{Price 1s. 6d., neatiy done up, \\ The Pocket Mredical Guide;}

Being a Popular Treatise on Diet and Regimen, Cold and its effects, and the Use and Doses of Medicine; the whole selected from the latest and best authorities, and carefully adapted for the use of families and non-professional readers.

\section{CONTENTS.}

Part I. ON DIET AND REgIMEN.

Introduction-Chap. I. General Anatomy of the Digestive Apparatus. 1. Of the Alimentary Canal. 2. Of the Glands subservient to digestion. 3. Of the connexion between the digestive and other functions.-Chap. II. Of Hunger and Thirst. - Chap. III. What is the natural Food of man?-Chap. IV. Of Alimentary Substances. 1. Aliments derived from the Vegetable kingdom. 2. Aliments derived from the Animal kingdom. 3. Of Condiments. 4. Of Drinks. -Chap. V. Rules for taking food.-Chap. V1. Of Indigestion.

PART II.-ON EXPOSURE TO COLD AND ITS EFFECTS.

Chap. I. Of Cold in general.-Chap. II. Of the diseases caused by exposure to cold. 1. The direct consequences of exposure to cold. 2. The indirect consequences of exposure to cold ; Fever, Catarrh, Intiuenza, Cough, Asthma, Consumption, Inflammation of the Larynx, Croup, Inflammation of the Lungs, Sore Throat, Kheumatism, Diarrhœa, Chilblains, Oplithalmia.-Chap. III. Of the means whereby the bad effects of exposure to cold may be avoided.

PART III.-ON THE USE AND DOSES OF MEDICINE.

Art of proscribing medicines-Laxative medicines, Emetics, Anodynes, Astringents, Tonics.

"A book that no family in town or country ought to be without."-Kilmarnock Journal.

"This, though a small, is a very useful manual. The editor evinces aptitude in the art of condensation, and the publisher, Mr. M'Phun, a laudable proneness to exemplify in book-making one of the very best maxims promulgated by the disciples of Bentham-the maximum of utility in the menimum of space."-Dumfries Courier. 
Price 1s. 6d.

\section{The Shorthand Writer's Pocket Guide;}

Conveying a full knowledge of this useful Art, on a new and highly improved System, by which may be written 150 words per minute. Illustrated by an entire copy of the Scripture Paraphrases used by the Church of Scotland; and the Thirty-Nine Articles of the Church of England. By J. GARDNER, Teacher, Antigua Place, Glasgow.

IV.

Price Is. 6d.

Uniform with the Mother's Pocket Medicax Guide, but containing a great deal more matter.

\section{The Pocket Guide to Domestic Cookery:}

Being the most Complete and Concise System extant of Practical Domestic Cookery. By a LADY. To which are added, instructions for Trussing and Carving; with plates.

Not a single Recipe will be given in this volume that has not been practised by tbe Authoress.

\section{V.}

Price 1s. 6d.

\section{The IMother's Pocket INedical}

\section{Gruide:}

Or a Treatise on the Physical Education and Diseases of Children. Compiled for popular use from the writings of Drs. Eiberle, Dewees, Buyns, Ryan, Kennedy, and others. By a Physician. 


\section{4}

\section{VI.}

The FIFTH EDITION, in Foolscap 8vo. Price 6s. Boards, of

\section{The Anatomy of Drunkenness;}

By Robert Macnish, Author of "The Philosophy of Sleep," and Member of the Faculty of Physicians and Surgeons of Glasgow.

Contents. - Chap.1. Preliminary Observations. 2. Causes of Drunkenness. 3. Phenomena of Drunkenness. 4. Drunkenness modified by Temperament. 5. Drunkenness modified by the inebriating Agent. 6. Enumeration of the less common Intoxicating Agents. 7. Differences in the Action of Opium and Alcohol. 8. Physiology of Drunkenness. 9. Method of curing the Fit of Drunkenness. 10. Pathology of Drunkenness. 11. Sleep of Drunkards. 12. Spontaneous Combustion of Drunkards. 13. Drunkenness Judicially considered. 14. Method of curing the Habit of Drunkenness. 15. Temperance Societies. 16. Advice to inveterate Drunkards. 17. Effects of Intoxicating Agents on Nurses and Children. 18. Liquor's not always hurtful.

"This little book is evidently the production of a man of genius. The style is singularly neat, terse, concise, and vigorous, far beyond the reach of any ordinary mind; the strain of sentiment is such as does infinite honour to the Author's heart; and the observation of human life, by which every page is characterized, speaks a bold, active, and philosophical intellect. As a medical treatise it is excellent ; and to those who stand in need of advice and warning, it is worth a bundred sermons."-Blackwood's Magazine.

"If every man addicted to this dreadful vice could be induced, in some lucid interval, to read this volume with attention, it would go far to put him out of conceit with the practice. If his own observation and experience had not taught him what a complicated evil drunkenness is, this volume would at least bring to his remembrance many things which it is of the greatest importance he should know before he is for ever ruined."-Entertaining Press. 


\section{VII.}

\section{SECOND EDITION,}

\section{In One Volume Foolscap 8vo., Price 7s.}

\section{The Philosophy of Sleep;}

By Robert Macnish, Member of the Faculty of Physicians and Surgeons of Glasgow.

Contents. - Chapter 1. Introduction. 2. Sleep in General. 3. Dreaming. 4. Prophetic Power of Dreams. 5. Night-Mare. 6. Day-Mare. 7. Sleep-Walking. 8. SleepTalking. 9. Sleeplessness. 10. Drowsiness. 11. Protracted Sleep. 12. Sleep from Cold. 13. Trance. 14. Waking Dreams. 15. Spectral Illusions. 16. Reverie. 17. Abstraction. 18. Sleep of Plants. 19. General Management of Sleep.

"The Second Edition has been enriched with many important additions; in particular a long chapter on Spectral Illusions-one of the most interesting portions of the work. We have seldom met with a work more worthy of a place in every well-furnished library. It will interest equally the reader for amusement and the philosophical thinker."Edinburgh Phrenological Journal.

"This is one of the most interesting and delightful volumes we have for a long time met with. It is full of amusement and instruction. Over its details is thrown that luminousness which alone flows from original genius."Edinburgh Evening Post.

"We have been captivated by the eloquence-we haa almost said the poetry of its descriptions; and, on the whole, we must say that we consider it to be one of the most valuable and amusing books of philosophy we have met with for this long time past."-London Medical Gazette.

"A work which will be perused with interest and delight. It may be considered the most valuable contribution which philosophy, poetry, and physical science in agreeable combination, have lately made to the illustration of the study of man's nature, viewed in close alliance with his 'being's end and aim." "-Edinburgh Weekly Journal. 
VIII.

Just Published in Foolscap 8vo., Price 5s.

\section{The Book of Aphorisms.}

BY A MODERN PYTHAGOREAN.

"We should have noticed this spirited and delightful volume long ere now-and would have made a point of doing so, had its tendency and nature been in the least degree ephemeral; but to the reader of the Anatomy of Drunkenness and the Philosophy of Sleep, it will require no rhetorical effort of ours to show that no serious and deliberate publication of Dr. Macnish's can be so. These two acknowledged works have been before the world for years-they rose instantly into popularity, and continue popular; and we have no doubt that this last brochure, 'to make a third will join the former two,' in the good graces of the reading public. These Aphorisms exhibit keen observations of life, manners, and authorship -are gilded with the play of a delightful fancy ; and without the cynical moroseness of Rochefoucault, the pert paradox of Hazlitt, or the sententious indelicacy of Sterne; convey wholesome advices, and pleasant remarks, in a way that cannot fail to amuse while they instruct. Some are on light subjects, and some on weighty; and number three never predicts what number four is to tell us; but the variety is of itself charm. ing, and we sit down as it were to a breakfast a la fourchette, where one helps himself to tea, and another to coffee, a third commencing with a sliced tongue, and a fourth with devilled turkey, while a fifth prefers broiled salmon steak, and wonders at a sixth, his neighbour who is gobbling up German sausage.

"To review such a book as the present, which, so far as matter goes, has neither beginning, middle, nor end, and which, like the Hebrew, we may, if we choose, begin to read backward, were a preposterous undertaking. The only way is to give a dozen consecutive Aphorisms, by way of extract, opening the book at random.

"He who could write these six hundred and seventy-tive Aphorisms, could readily add a thousand more to them. Let him do so, and that speedily, in the shape of a second series. When both are lound together, they will make a delightful travelling companion.

"The getting up is exquisite in every respect. Well done, Glasgow ?"-Edinburgh Erening Post. 


\section{(}

\section{IX.}

Now Ready, Vols. I. II. and III., 5s. each.

\section{The Scottish Pulpit,}

Containing a Body of Original matter, nowhere to be met with in quality so superior, and at a price so very reasonable. The Sermons are by the most eminent living Divines of the Church of Scotland; and, for the most part, have either been furnished by the authors themselves, or corrected by them before appearing in print.

Scottish Pulpit, Vol: III. - "We hail the appearance of this volume with much pleasure. The extensive sale which the work enjoys, and deservedly enjoys, is a favourable symptom, or rather a gratifying proof, that feelings of christian piety still exist to an encouraging extent in our land. It would very greatly benefit society were such writings to become much more prevalent, and take the place of those, which under the name of politics or political economy, and under the pretence of teaching the art of Government, are souring men's minds, and rendering them turbulent, disconteuted, and unhappy. It signities very little for a man to have his head stuffed with crude undigested knowledge, which he probably will never have an opportunity to apply; but not so with the knowledge here communicated, because it is such as deeply interests every man, not only in his passage through this transitory scene of life, but in future and endless ages. The present volume contains upwards of 70 sermons, some of them by the most eminent ministers of which Scottish Ecclesiastical Literature can boast, while others are. from pens, whose owners, though not yet perhaps much known to fame, are in the fair way of obtaining it, if the sermons, under notice, be fair criteria of their merits. The volume, in addition to its other properties, is very handsomely printed. It is, moreover, embellished with a portrait of the late Rev. John Geddes, of whom a memoir is given. We recommend the volume, not as one worthy of a single perusal, and then to be laid aside and forgotten, but as one that may be perused and re-perused with increasing pleasure and increasing profit."Paisley Advertiser.

"The third volume of this excellent body of practical theology is completed; and its merits, we think, are even greater than those of the volumes by which it was preceded. There is a marked improvement in the style of the sermons, 
and to account for the superiority is not difficult. The utility of the work is now established, and clergymen, appreciating its merits, and knowing its extensive circulation, select with care the sermons they wish to appear in its pages. The Scottish Pulpit is a publication in which Christians of every denomination are interested. With party it has nothing to do. 'The diffusion of Christianity is its object, in a mode cheap, convenient, and elegant. In this age of cheap publications the idea of furnishing two sermons for twopence seemed to be merely the speculation of an ardent mind. The attempt, however, pleased the religious publie -the variety of the work continued to excite attention-its substantial matter ensured approbation, till, from ranking as a weekly production, it has assumed the loftier station of a standard publication of practical divinity. Nor is this strange. The sermons generally are, what such productione should be, calculated to improve the understanding and affect the heart, and from the peculiar circumstances under which they are furnished, they have an unction which few printed sermons possess. This publication, therefore, has just claims for general diffusion. Is the Christian fond to possess a sermon of his beloved minister? In the stillness of the Sabbath evening does he wish a work suitable for that day, and in unison with his feelings? Does the father, in the domestic circle on that evening, require a publication to instruct the minds of his household, and improve their hearts? Is the Christian, in the seclusion of a sick chamber, desirous of spiritual comfort? - to all these classes, how diversified soever their circumstances, the Scottish Pulpit is peculiarly adapted. The religious sailor, will find this work most suitable for a spare hour on Sunday. It will remind him of home, of his duty to himself, to his neighbour, and to his God. The pious shipmaster, who assembles his crew for religious purposes on Sabbath, would consult his own interest, and the spiritual welfare of those for whom he is deeply responsible, by adding to his religious exercises a selection from the pages of this work. We heartily recommend this publication to the patronage of the religious public; known, its merits will be acknowledged; and we are proud to have this work associated with the literature of Scotland. It is worthy of her press and of her pastors; and the publishers merit the warmest thanks for the manner in which the Scottish Pulpit has been conducted, and we sincerely trust their past and continued exertions will be fairly appreciated."-Greenock Advertiser. 
$\mathbf{x}$.

NEW Edition, Corrected, First Series complete, Five Volumes 8vo. Price £2.

\section{The Glasgow IIechanics' Maga= zine.}

Great pains have been bestowed upon the present Edition of this work in its progress through the press. Articies of temporary interest have been excluded, and in their place has been substituted such matter as will always prove useful to the man of science, thus rendering the work one of permanent utility on every subject connected with Science and the Arts.

"However much we have been led from time to time to speak in admiration of the work of a similar kind to this now Publishing in London, we cannot help expressing our opinion as still higher of the Glasgow Mechanics' Magazine. It appears to be conducted by a set of practical men, who understand well what they are about, and who are well calculated to execute the task they have undertaken. The plates are all engraved on copper, and in a manner not inferior to the most expensive Scientific Journals now publishing. All the London cheap Periodicals have only got wood engravings, which do not and cannot show the minute lines of Machinery half so well as a copperplate engraving."-Leeds Mercury.

XI.

TWENTY-SEVENTH EDITION.

Ihe Scottish Martyrs.

In Two Large Volumes 8vo.,

Biographia Scoticana:

Or a Brief Historical Account of the Most Eminent SCOTS wORTHIES, Noblemen, Gentlemen, Ministers, and others, who Testified or Suffered for the 
Cause of the Reformation in Scotland, from the beginning of the Sixteenth Century to the Year 1688; originally collected by John Howie of Lochgoin; now Revised, Corrected and Enlarged, by a Clergyman of the Church of Scotland. and Enriched with a Preface and Notes, by Wr. M'Gavin, Esq., Author of "The Protestant," \&c.

Volume I. contains Memoirs of the Lives of the Worthies. Volume II. contains the "Last Words and Dying Testimonies," "Cloud of Witnesses," "Naphtali," \&c. \&c. -To those who are already in possession of the first volume of this work, the second will be found an indispensable requisite, as without it the book is incomplete, and is deficient in by far the most important and interesting portion of the Biography of the Scottish Reformers.

"This is by far the best edition of this most remarkable work that has ever seen the light. He is not worthy the name of a Scot, who can be indifferent to the story of these immortal champions."-Evangelical Magazine.

"We hail with pleasure this new and greatly improved Edition. The external appearance is very creditable to the Publisher, and we have no doubt his well-meant zeal in publishing an improved edition of a work that must ever be dear to pious minds, will meet with the encouragement which it unquestionably deserves."-Edinburgh Christian Instructor.

XII.

SECOND EDITION OF THE NEW GAELIC DICTIONARY.

Now ready, in one handsome Octavo Volume, dedicated to his Grace the Duke of Gordon, Price 2ls.

\section{A Dictionary of the Gaelic Ian- guage,}

Containing many more Words than the Quarto Dictionaries; with their significations and various meanings in English; illustrated occasionally by suitable Examples and Phrases, and Etymological Remarks. The first Part contains Gaelic-English, the Second English-Gaelic, which are given much fuller than in any of the Quarto 
Dictionaries. By the Rev. Dr. MrLeod, Campsie, the Rev. Principal Dewar, Aberdeen.

"The Rev. Dr's. M'Leod and Dewar are already advantageously known to the public as eminent Gaelic Scholars, and we think their Dictionary promises fair to extend their reputation as benefactors to the Highlands. * * * The present publication will have all the advantages of an abridgment from the Society's large work, with some peculiar to itself, as being to a considerable extent ORIGINAL. Many new words are added, and new phrases are given, especially with regard to the changes effected upon the word by prepositions, prefixes, and affixes, which are very common in Gaelic. To the Highland Student and the Highland Minister it is unnecessary to recommend it, since we know that by them such a work has been long wished for; and a slight glance at the present will be sufficient to convince them of its value."-Eäinburgh Literary Journal, Dec. 1829.

"We have now the complete work before us, and we are much pleased to find that, instead of cause to retract, we have rather to add to the praise we formerly felt it our duty to bestow on the labours of Drs. M'Leod and Dewar."Ibid. Jan. 1831.

\section{XIII.}

\section{The Gaelic IMLessenger.}

Conducted by tne Rev. Dr. M'Leod of Campsie, assisted by a numerous circle of Celtic Scholars. Complete in 2 Vols. in Boards, price 6s. 6d. each, or with the Sermons 8s. each Vol.

" This is truly a literary curiosity. A periodical in the language of Ossian. We congratulate our Highland countrymen in particular, and the friends of knowledge and civilization in general, upon the appearance of this excellent Miscellany."-Edinburgh Literary Gazette.

XIV.

\section{The Notation of Music Simplified;}

Being the Development of a System, in which the Characters employed in the Notation of Language are applied to the Notation of Music. By Alexander Macdonald. 
$\mathrm{XV}$.

Seventh Edition, neatly done up in pocket size, Price 19.

\section{A Calechism of Phrenology,}

Illustrative of the Principles of that Science. By a Mem. ber of the Phrenological Society of Edinburgh.

This Work contains all that is requisite for the information of the General Reader on Phrenology. All the leading Facts and Principles of the Science are fully detailed, and the whole is illustrated with Engravings.

"The utility of this manual is unquestionable, for whatever progress the science it is intended to illustrate may be making, it is evident that its study should not be entirely omitted even in the most general education. The arrangement of the work is admirable. The utmost perspicuity prevails in every page. The public may be assured of its high claims to their attention, firom the facility with which the principles of the science are unfolded before them; from the philosophic tone in which the subject is treated, and from the unassuming, morlest manner in which its appeals are made."-Alexander's East India Magazine.

"This is a brief Manual of Phrenology, in the form of a Catechism, intended for the use of individuals who cannot bestow much time or money on the study of it. It combines accuracy, clearness and brevity, and is scrupulously correct in doctrine.

"After describing the different organs, the work contains 'general questions,' in which the effects of education, temperament, size, combinations, \&c., are discussed. It contains a neatly engraved copy of the Edinburgh Phrenological bust; and, on the whole, is a commendable and useful publication. It is neatly printed, and sold very cheap."-Edinburgh Phrenological Journal.

\section{XVI.}

\section{A Brief Iistory of the Protestant 2eformation.}

New Edition, with Corrections and Additions, in One Vol, Price 4s. Boards.

In a Series of Letters addressed to WILLIAM COB. BETT, in coilseriuence of the Mlisrepresentations and 
Aspersions contained in his " History of the Protestant Reformation in Britain and Ireland." By WM. M'GAviN, isq. Author of "The Protestant."

"Those who wish to see Mr. Cobbett more than matched, ehould possess themselves of this valuable publication. It is not saying too much of Mr. M'Gavin to assert that he is one of the most enlightened Protestants in Christendom. 'The whole controversy stand; before his mind in the order' of perfect arrangement, and Mr. Cobbett appears like a child in the hands of a giant. Posterity will gratefully acknowledge its obligations to this incomparable advocate." -Evangelical Magazine.

\section{XVII.}

Neat pocket size, Price 1s. 6 d. in Boards.

\section{Treatise on Baptism.}

A Practical Treatise on the Spiritual Import of Baptism, and the duties connected with the Observance of the Ordinance. By the Rev. John 'Thолsоn, Minister of Shettleston.

"This is a work which will, and ought, to make its way, where many more ponderous and learned treatises on the subject will be refused admittance. The truths regarding the nature and practical bearing of the ordinance of baptism are correctly and clearly stated; and the duties binding both upon parents and children, in connexion with the solemn ordinance, are enforced in some instances with a natural eloquence which cannot fail to reach the heart, because every reader will feel that the sentiments come from the heart. It is of importance that Christian parents should be reminded of the duties which it is incumbent on them to discharge towards their baptized children, especially in this age, when too many obviously regard the ordinance by which they are admitted into the visible church in no other light than a customary form with which it is disrespectful not to comply ; and it is of importance, also, that such should be provided with a work so moderate in compass as this, to serve both as a mauual for direction, and a stimulus to urge them on to duty. The author has not served the cause of Christianity by throwing any new light ujon the subject; but we are mistaken if he has not rendered a very important service to the cause of practical godliness, by bringing with- 
in the reach of all, a clear and forcible exhibition of vital truth, and if parents are not led by it, in many instances, to the fulfilment of their solemn engagements, and induced to a more rigid adherence to their vows. We heartily join in the author's prayer, and trust he will enjoy the ' unspeakable satisfaction' of making many 'a salutary and saving impression,' by the little volume now before us."-Presbyterian Review.

XVIII.

\section{Church Fstablishments Defended,}

Being a Review of the Speeches delivered in Dr. Beattie's Chapel, by the leading men of the Voluntary Chureh Association. By a Cliurchman.

"The Churchman's" Second Defence of Church Establishments, being a Second Review of the Speeehes in which the argument against Establishments, drawn from the state of religion in the United States of America, is fully considered, and ample information of the subject adduced.

The Christian Instructor in reviewing the various works on this subject, of the second of these, says-"This is a powerful pamphlet. To those who wish to have only one pamphlet upon the subject, this is the one that we recommend." This is no mean praise, considering that the pens of the ablest and most eloquent writers of the presert day have been employed on the subject.

"For a more particular refutation," says Dr. Patrick $M$ 'Farlane, in a note to his speech, "of the argument of the Voluntaries from America, let the reader peruse that unanswerable pamphlet entitled 'a Second Defence." "

" See ample details on this sulject in the 'the Churchman's' able and triumphant 'Second Defence." "-Presbyterian Magnzine.

These two pamphlets may now be had neatly bound in Cloth.

XIX.

\section{A Careful and Strict Inquiry}

Into the Pretensions and Designs of Dr. Heugh; or, his "Considerations on Civil Establishments of Christianity" plainly discovered to be full of specimens of ignorance, most absurd and contradictory arguments, and altogether to have been published very inconsiderately. - With some 


\section{XX.}

\section{The Church of ScotIand Iragazine.}

Contrants. - 1. To Readers and Correspondents :-Union of Orthodox Seceders with the Church of Ssotland-Protestantism-Atheism-The Union of Infidels with Voluntaries-To the Editor of the Record-Missionary Biography - Ysalmody-Revenues of the Church of England.-2. Scripture Evidence in Favour of Establishments. By J. E. Gordon, Esq., late M.P. for Dundalk-No. 2. The Patriarchal Dispensation.-3. Extension of the Church-St. Andrew's Church, Ramsbottom, Lancashire.-4. Extracts from Distinguished Writers. -5. Church Property not Originally the Exclusive Property of Roman Catholics. 6. Dissenting Endowments.-7. Voluntary Church Prineiples both of a Revolutionary and Infidel Nature. - 8. Present Condition of the Established Church.-9. Notices of Books : - The Expediency of a Secure Provision for the Ministers of the Gospel-Speeches delivered at a Mieeting held at Arbroath-Wisdom of the Secession Magazine-Memoir of the Rev. Elias Cornelius.-10. The Church of Scotland, the Friend of Freedom.-11. Voluntary Denouncement and Reverence for Scripture.

"We are pleased with the whole series of this new periodical, so admirably adapted to the times in which we live, and long wanted by the Church in Scotland. It is conducted with great talent; and in addition to its other merits, has unanswerable claims upon public patronage from its cheapness. It is sold at Sixpence! No clergyman of the Church of Scotland, therefore, and no lay member of that Church who has any regard for the venerable Establishment, has any excuse if this periodical do not appear on the breakfast table as regularly as the months come."-Liverpool Standard.

XXI.

\section{America at One View.}

On a very Large Sheet, beautifully printed at the Glasgow University Press, Price 1s. 6 d., or varnished on canvass and roller, Price 6s. $6 \mathrm{~d}$.

Bell's Statistical Sheet Atlas of the United States of North America. 
XXII.

NEW Edition; with a beautiful Engraving of the King William Steam Carriage, in Octavo, Price 18.

A DESCRIPTIVE AND HISTORICAL ACCOUNT OF

\section{The Iiverpool and Manchester Railway,}

From its First Projection to the Present Time: Containing all the Facts and Information that have yet appeared on the subject; with numerous Interesting and Curious Original Details, Estimates of Expenses, \&c., \&c. By Joseph Kirwan, Civil Engineer.

"Those who are at this time embarking their capital in the erection of Railways throughout the country, would do well to peruse with care a small work recently published by Joseph Kirwan, civil engineer. It contains, in a narration of the rise, progress and completion of the Liverpool and Manchester Railway, a host of information on the subject; and, what must be of infinite importance to those engaged in similar enterprises, it is all of a PRACTICAL nature. The details are ample, the facts numerous, and the calculations are made with the utmost accuracy and precision."-Edinburgh Advertiser.

\section{XXIII.}

In Two neat Pocket Volumes, Price 9s. The Spirit of British Song.

With illustrative and Biographical Notes, by the late JOHN GOLDIE.

"Among the innumerable collections of Songs which are continually issuing from the press, we have not met with one deserving more universal patronage, than the one now before us. Judging from the first four Numbers, which have been handed to us, we can safely say it is the best we have yet seen. It is really what it professes to be- 'THE SPIRIT OF BRITISH SONG ;' and gives only what it promises -the Popular Melodies of the day. A publication of this kind, we conceive was much wanted. No selection was obtainable at a reasonable price, divested of all the obsolete rubbish misnamed songs, which are here judiciously discarded, and at the same time free from what most Song Books are crammed with: viz., original trash." - The Telescope. 
XXIV.

In one Volume 12mo. with an Engraving of the Arms of the Incorporation of Bakers, Price 5s.

\section{The Practical Baker and Confec- tioner's Assistant,}

Being a Comprehensive View of every thing relative to the Baking of Loaf and Fancy Bread, on both the Ancient and Modern Systems; with a great variety of Practical Receipts in Pastry, Confectionary, Candies and Preserves, Cordials, Wines, \&c. ; and the various methods - of making Artificial Yeast. By John Turcan, baker.

"Moreover, this book is a perfect repository of every thing relating to the subject, which he has undertaken to discuss. The whole mystery of baking and confectionary is fully laid open; and by the simple and judicious directions laid down, any one may practise for himself the operations of these universally interesting arts. We doubt not that the work will be found highly useful to the trade; and we dismiss it with every wish for that success which it go r 'ell deserves."-Edinburgh Evening Post.

$\mathrm{XXV}$.

In Monthly Numbers, Price $2 d$.

The Child's IVagazine;

Or, Tales for the Nursery.

by Mrs. M‘GREGOR, Author of "Maternal Duty," \&c., \&c.

XXVI.

Neatly Printed in Pocket size, Price 6d.

\section{The Casquet;}

A Collection of the best Songs in the GAELIC LAN-

G UA GE. Selected by James Munroe.

"It contains as much closely and neatly printed matter in Gaelic, for Sixpence, as we have ever seen offered for the same money in English."-Scots Times.

\section{XXVII. \\ IV'Phun's Idition of the Scotch Reform Act. \\ Price Threepence.}

This is the most accurate and most comprehensive of all the Abridgments of the Act yet published. 
XXVIII.

THIRD EDITION, Price 2s. 6d.

With the Sectch Law regarding the Sale and Warranty of Horses.

\section{Advice to Purchasers of Iorses}

Being a Short and Familiar Treatise on the Exterior Conformation of the Horse, the Nature of Soundness and Unsoundness, the Laws relating to Sale and Warranty, with Copious Directions for Discovering Unsoundness prior to purchase.

By J. Stewart, Veterinary Surgeon, and Professor of Veterinary Surgery in the Andersonian University.

" The buyer hath need of a hundred eyes, But the seller of only one."

"Persons who have occasion to buy or sell horses would derive much instruction from this little manual, which treats of the exterior conformation of the horse, the nature of soundness and unsoundness, and the laws relating to sale and warranty, with copious directions for discovering unsoundness prior to purchasing. The author is a scientific man, and his work is popularly written, and likely to be useful."-Leeds Mercury.

" This Manual, though of small size, is far from being of small value, and cannot fail to be useful not only to farmers, innkeepers, and others engaged in posting, but also to every one who may have occasion to purcbase a useful and serviceable horse. If a person make himself master of the maxims it contains he will be fully prepared to select a sound animal, as well as to detect and prevent the imposition of ordinary horse-dealers. It also contains an exposé of the laws relating to sale and warranty of horses, which cannot be too well known, because to borrow the motto of the work, "the buyer hath need of a hundred eyes, but the seller of only one." - Stirling Journal.

"This is a well-composed and useful little volume." dgricultural Journal.

"We would recommend no person to purchase a horse without having previously purchased and perused Mr. Stewart's book of advice."-Glasgow Chronicle.

" This is an exceedingly useful little volume, which every Tyro in the art of horse dealing should lose no time in becoming possessed of."-Dumfries Courier. 


317 
